\title{
20. SUBMARINE GEOLOGY OF THE SOUTH FIJI BASIN
}

\author{
Gordon H. Packham and Allan Terrill, Department of Geology and Geophysics, \\ University of Sydney, NSW, Australia
}

\section{INTRODUCTION}

The South Fiji Basin (Figure 1) is a triangular-shaped marginal sea, bounded on the east by the Lau Ridge and on the north by the Hunter Fracture Zone and the South New Hebrides Trench. The western boundary of the basin is the Norfolk Ridge in the north and the Three Kings Rise in the south. The short southern margin of the basin is the continental margin of the North Island of New Zealand. The area of the basin floor is 800,000 $\mathrm{km}^{2}$, and the basin floor lies between 4000 and 4700 meters below sea level.

The general bathymetry of the region is covered by Chart 12 of The Scripps Bathymetry of the South Pacific (Mammerickx et al., 1971). In addition, the New Zealand Oceanographic Institute has published maps of a major part of the basin on a scale of $1: 1,000,000$ with 250 -meter contours. Kandavu (Cullen, in press) covers the northern quarter of the basin, and Three Kings (van der Lingen, 1968) covers the southern quarter. The intervening sheet, Egeria, is in preparation. Seismic refraction measurements (Shor et al., 1971) and heat-flow measurements (Sclater et al., 1972) have been made as parts of a more regional study. The eastern part of the basin has been examined by Karig (1970a, 1970b) in his study of the Lau-Havre Basin. An account of Site 205 drilled in the eastern part of the basin is to be found in the DSDP Leg 21 Initial Report (Burns, Andrews et al., 1973). The same report contains an account of the volcanic products in the sediments at Site 205 (Churkin and Packham, 1973).

This present study of the basin has drawn its data from a number of sources other than published information. Further study of the sediments from Site 205 has been undertaken accompanying a comparative study of Site 285 detritus, beyond that in the Site Report (this volume). The map (Plate 1) has been compiled principally from the GEBCO (The General Bathymetric Chart of the Oceans) sounding sheets, supplied by the Royal New Zealand Navy, seismic profiles from the NOVA Expedition, the R/V Kana Keoki site survey cruise for Leg 21, D/V Glomar Challenger Legs 21 and 30. Additional bathymetric data were supplied by the New Zealand Oceanographic Institute (Planksed 1). The nomenclature of all the bathymetric features follows the revised version of Wanoa and Lewis (1972) except for the South Fiji Ridge; the better known term, the Lau Ridge, is used in its place.

\section{BATHYMETRY}

The bathymetric map (Plate 1) was prepared by first contouring the GEBCO sounding sheets, rejecting conflicting tracks, and then adding satellite navigation controlled data (Kana Keoki, Glomar Challenger, and
Tangaroa-Planksed 1). Further rejection of conflicting tracks took place at that stage. The number of lines removed at this stage was surprisingly small. This gives us confidence in most of the information used.

The main bathymetric features are shown in Figure 1, and they will be described briefly in turn. Further discussion is included in the account of the seismic profiles that follows later.

\section{Lau-Colville Ridge}

To the east of the Lau-Colville Ridge that bounds the eastern side of the basin lies the Lau-Havre Trough. It is substantially shallower, narrower, and younger than the South Fiji Basin. According to the drilling results of Leg 21 (Burns, Andrews, et al., 1973), its formation commenced at the end of the Miocene.

The Lau-Colville Ridge widens towards the north and becomes shallower. Islands are confined to the northern third of the ridge. The southernmost of the islands are reefs, but the northern ones have volcanic sequences and limestones exposed.

The eastern flank of the Lau-Colville Ridge is simple, falling steeply into the Lau-Havre Trough; by contrast, the western flank is variable along its length. North of $21^{\circ} \mathrm{S}$ the South Fiji Basin shallows, and the boundary between the basin and the ridge is less sharp than to the south. Between $21^{\circ} \mathrm{S}$ and $23^{\circ} \mathrm{S}$, there is a break of slope into the basin at 3500 meters. From $23^{\circ} \mathrm{S}$ to $30^{\circ} \mathrm{S}$, the western flank is much broader and has subsidiary basins and ridges developed on it. These features have a trend a little west of north, while the Lau Ridge trends a little east of north. Between $29^{\circ} \mathrm{S}$ and $30^{\circ} \mathrm{S}$, a prominent ridge has a trend of about $70^{\circ}$. This parallels ridges developed within the basin. The break of slope into the basin is generally at 4000 meters. An abrupt westerly extension of the lower slope occurs at $27.5^{\circ} \mathrm{S}$ and narrows gradually southward. From $30^{\circ} \mathrm{S}$ to $33^{\circ} \mathrm{S}$ the ridge is relatively narrow but widens to the south, and its western flank merges into a region of complex bathymetry adjacent to New Zealand. This wider section has ridges and basins trending at about $60^{\circ}$. South of $30^{\circ} \mathrm{S}$ there is a distinct decrease of slope at 3500 meters on the western ridge flank.

North of $31.5^{\circ} \mathrm{S}$ the Lau Ridge crest consists of a series of elevations mostly elongated parallel to the length of the ridge. The southernmost islands are at $24^{\circ} \mathrm{S}$ (Figure 2). From $26^{\circ} \mathrm{S}$ northwards the gaps between the ridge crest elevations are at about 800 meters. At $30^{\circ} \mathrm{S}$, they are at 1300 meters. Between $26^{\circ} \mathrm{S}$ and $31.5^{\circ} \mathrm{S}$ the gaps are at $1100-1300$ meters and the ridge crest deepens from 500 to 800 meters below sea level. South of $31^{\circ} 30^{\prime} \mathrm{S}$ the crest of the ridge deepens substantially and becomes much narrower and rougher. The deeper parts of the ridge crest are around 2300 


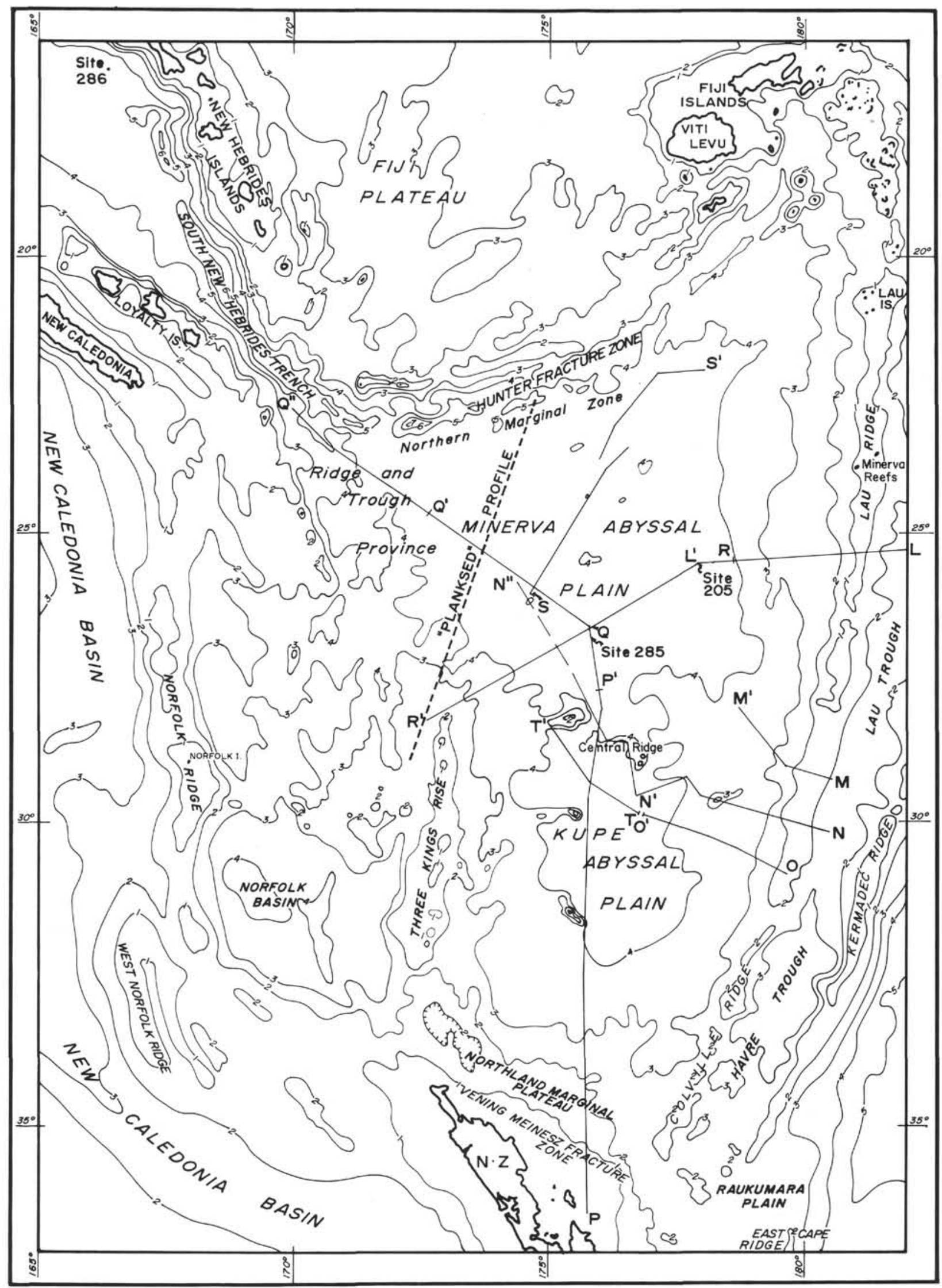

Figure 1. Principal features of the South Fiji Basin and the surrounding region showing seismic profiles and DSDP sites. 
meters in the southern part. South of $32^{\circ} 30^{\prime} \mathrm{S}$ the Tonga Ridge becomes narrower and deeper in the same way.

\section{New Zealand Slope}

The upper part of the slope is broken by a scarp, the "Vening Meinesz Fracture Zone" (van der Linden, 1967). Contouring suggests that this structure is a series of en echelon features trending at $130^{\circ}$ rather than a continuous fracture. The scarp is 1000 meters high on the Leg 30 crossing of it. Below the scarp is a region of irregular depressions and ridges that constitutes an irregular marginal plateau at about 2000 meters. The outer boundary of the plateau is a steep slope at the foot of which, at 3500 meters, there is a sudden decrease in gradient. The plateau is here named the Northland Marginal Plateau; it extends from north of Three Kings Island to the Colville Ridge. An analogous feature, the Raukumara Plain, occurs east of the Tonga Ridge off East Cape (Karig, 1970a). On the western end of the plateau, south of the Three Kings Rise is the Whangaroa Basin, a broad feature $150 \mathrm{~km}$ by $50 \mathrm{~km}$ elongated parallel to the "Vening Meinesz Fracture Zone."

\section{Three Kings Rise-Norfolk Ridge}

The Three Kings Rise is the eastern ridge of a region of complex bathymetry that links New Zealand and
New Caledonia. The western ridge is the Norfolk Ridge. Within the ridge complex is a number of small basins and troughs, the largest of which is the Norfolk Basin lying west of the southern half of the Three Kings Rise.

On the Scripps Southern Pacific bathymetric map, Chart 12, the Three Kings Rise is shown as truncated sharply by the Cook Fracture Zone. Although the bathymetric data from Planksed 1 indicated two scarps, one of 1000 meters and a second of 2000 meters at the northern end of the ridge (Figure 3), no other lines cross a similar feature. The existence of the fracture zone cannot be established on the information we have.

The trend of ridges and troughs in the Three Kings Rise region is mainly north-south except at the eastern edge of the ridge, where most of them run at about $60^{\circ}$ $70^{\circ}$

North of the Three Kings Rise the South Fiji Basin adjoins the Norfolk Ridge. The boundary between the ridge and the basin is indistinct. The region of rough sea floor in the northwest of the basin appearing to pass gradationally into the ridge. A north-south ridge that runs into the basin has the appearance of being an extension of the Three Kings Rise displaced $100 \mathrm{~km}$ to the west. Not enough of the Norfolk Ridge has been contoured to determine the pattern of the bathymetry. The situation is more complex than is shown on the Scripps map.

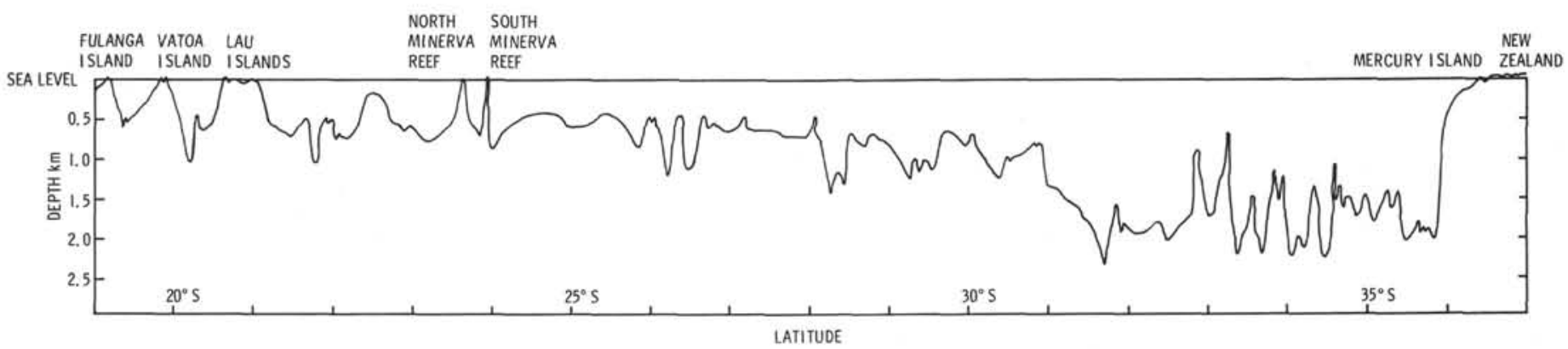

Figure 2. Projected profile along the crest of the Lau-Colville Ridge.

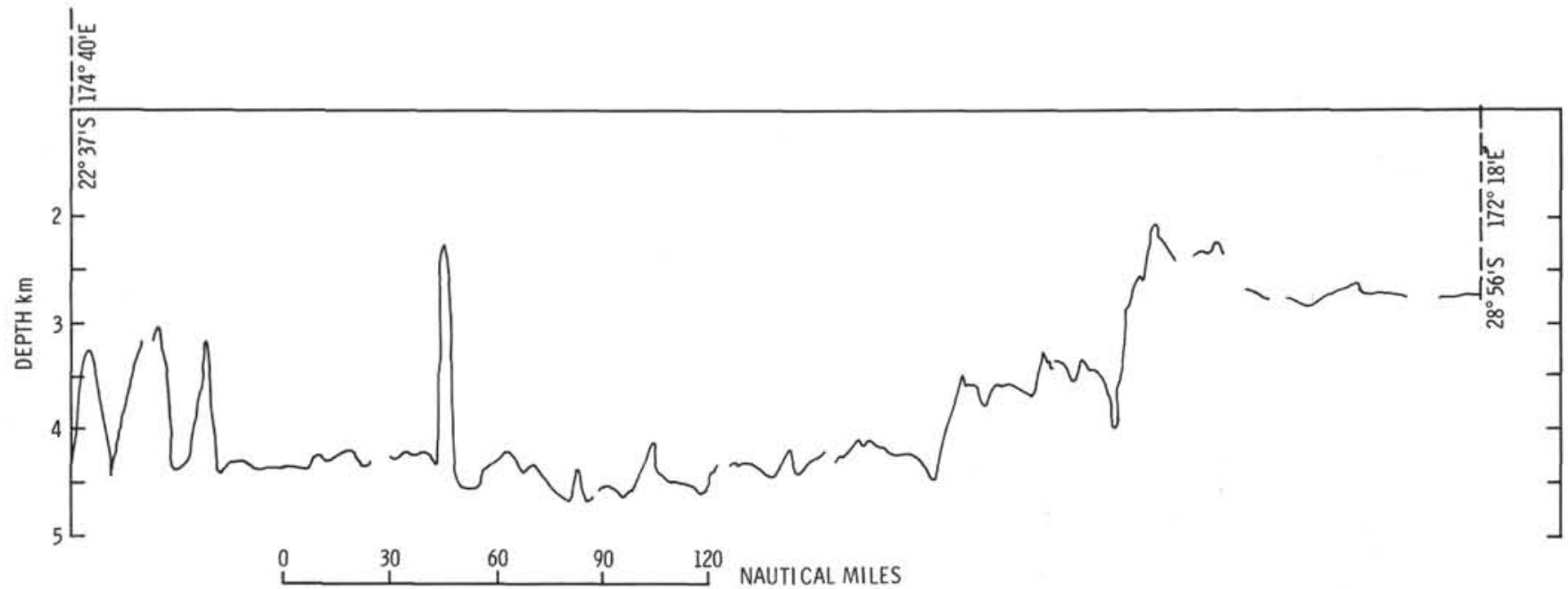

Figure 3. "Planksed 1" bathymetric profile across the northern part of the South Fiji Basin. 


\section{South Fiji Basin}

Five main subdivisions of the South Fiji Basin can be recognized: (a) the Kupe Abyssal Plain, (b) the Minerva Abyssal Plain, (c) the central ridge, (d) ridge and trough province, and (e) the northern marginal zone.

\section{Kupe Abyssal Plain}

In the southern part of the basin, the sea floor slopes gently down towards the north. Over most of the area the water depth is 4000 to 4300 meters. At the southern margin the abyssal plain passes into a rise-like zone with a steeper gradient. The bathymetric map suggests that a similar feature occurs on the eastern and western margins as well. However, one of the two seismic profiles (Plate 4) across the eastern margin shows a scarp. The name applied to the abyssal plain is a new one. It is named after the Maori who discovered New Zealand in about 983 A.D.

\section{Minerva Abyssal Plain}

This feature is here named after the southernmost reef on the Lau Ridge. The abyssal plain occupies about half of the area of the basin and abuts against the Lau Ridge in the east and extends west to the Three Kings RiseNorfolk Ridge. The break of slope at the foot of the Lau Ridge is at 4000 meters in the southeast. The plain surface drops 200 meters in about $20 \mathrm{~km}$ then slopes gently to the west reaching a maximum depth of 4800 meters. There is an irregular hollow in the southwest corner of the plain. A series of ridges rises from the plain in a line running northwards from the southwest extremity of the plain. The ridges have a trend of $60^{\circ}$ to $70^{\circ}$ and typically rise to a depth of around 4000 meters.

In the north, the surface of the plain has broad ridges 100-300 meters high paralleling the Hunter Fracture Zone. In the northeast, the surface of the plain rises, and the break of slope at the foot of the Lau Ridge is at 3500 meters, some 500 meters shallower than in the south. In the northwest, the plain ends against ridges east of the Norfolk Ridge.

\section{Central Ridge}

A ridge of a roughly $\mathrm{S}$ shape separates the two abyssal plains. It is over $100 \mathrm{~km}$ long, has rough topography, and rises to a depth of 3000 meters.

\section{Ridge and Trough Province}

In the northwestern part of the basin bordering the Norfolk Ridge is an area of rougher topography. There is a tendency for the ridges in the eastern part of this province to run parallel to the ridges that rise from the Minerva Abyssal Plain, but elsewhere no clear pattern can be seen.

\section{Northern Marginal Zone}

The northern margin of the basin adjacent to the Hunter Fracture Zone has more irregular bathymetry than elsewhere, and both troughs and ridges are developed there. These have a relief of up to 1500 meters above and below the surface to the south (see Figure 3).

\section{DRILLING RESULTS IN THE SOUTH FIJI BASIN}

The stratigraphic columns of the sites drilled in the basin are given in Figure 4 and their locations are shown in Figure 1. The middle Miocene and younger sequences at the two sites are lithologically similar, but pre-middle Miocene sediments were intersected only at Site 205. Drilling at Site 285 terminated at 564.8 meters in a diabase sill. At Site 205 the mid-Miocene section is unconformably underlain by mid and upper Oligocene oozes. Drilling terminated at this site when pillow basalts were intersected at 337 meters.

At both sites there are thick volcaniclastic sequences with varying quantities of biogenic components, overlain by biogenic oozes with varying amounts of volcaniclastic components. These are in turn overlain by thin sequences of iron oxide micronodule and zeolite-rich unfossiliferous clays. These "abyssal red clays" were deposited below the depth of total solution of nannoplankton.

The sediment accumulation curves (Figures 5 and 6 ) were constructed using the nannofossil zonal determinations of Bukry (1973) for Site 205 and those of Bukry (this volume) for Site 285 . The time scale used was that of Berggren (1972). Detailed comparison of the

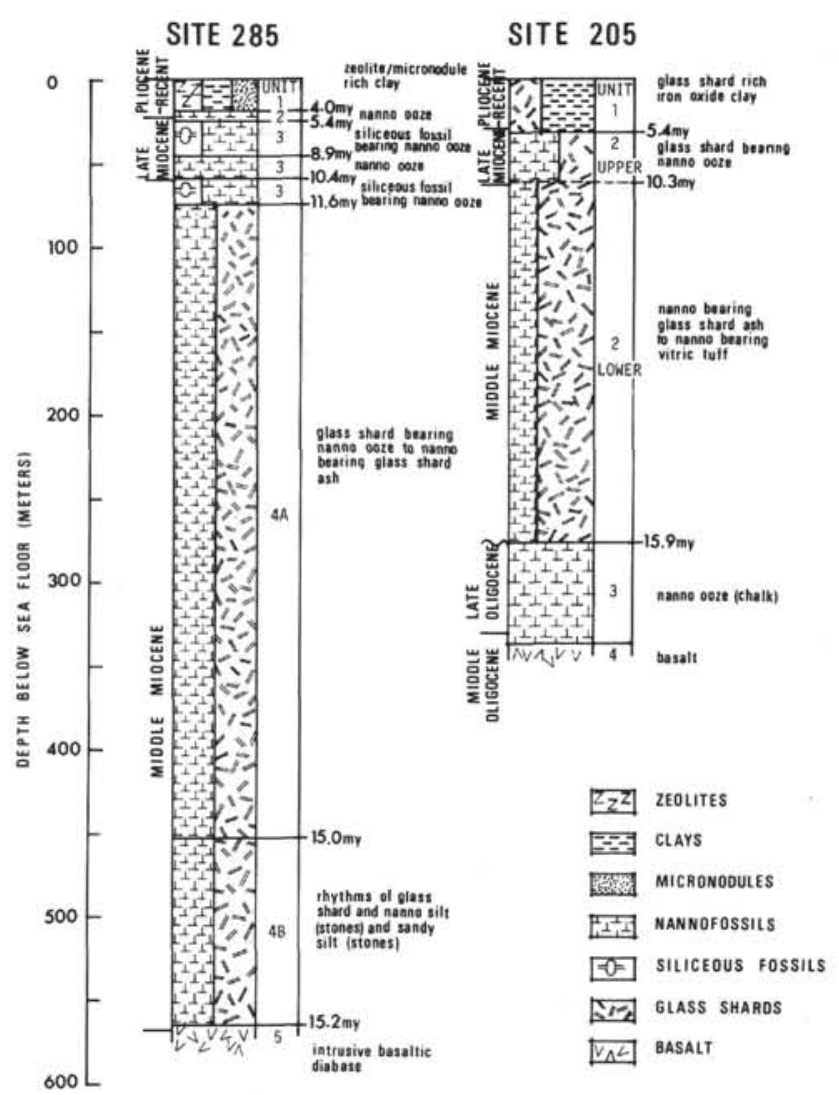

Figure 4. Stratigraphic columns of Sites 285 and 205. Lithologic units used are shipboard subdivisions. Subunits in Unit 3 have been subsequently eliminated, and the Unit 3-Unit 4 boundary is raised slightly. 


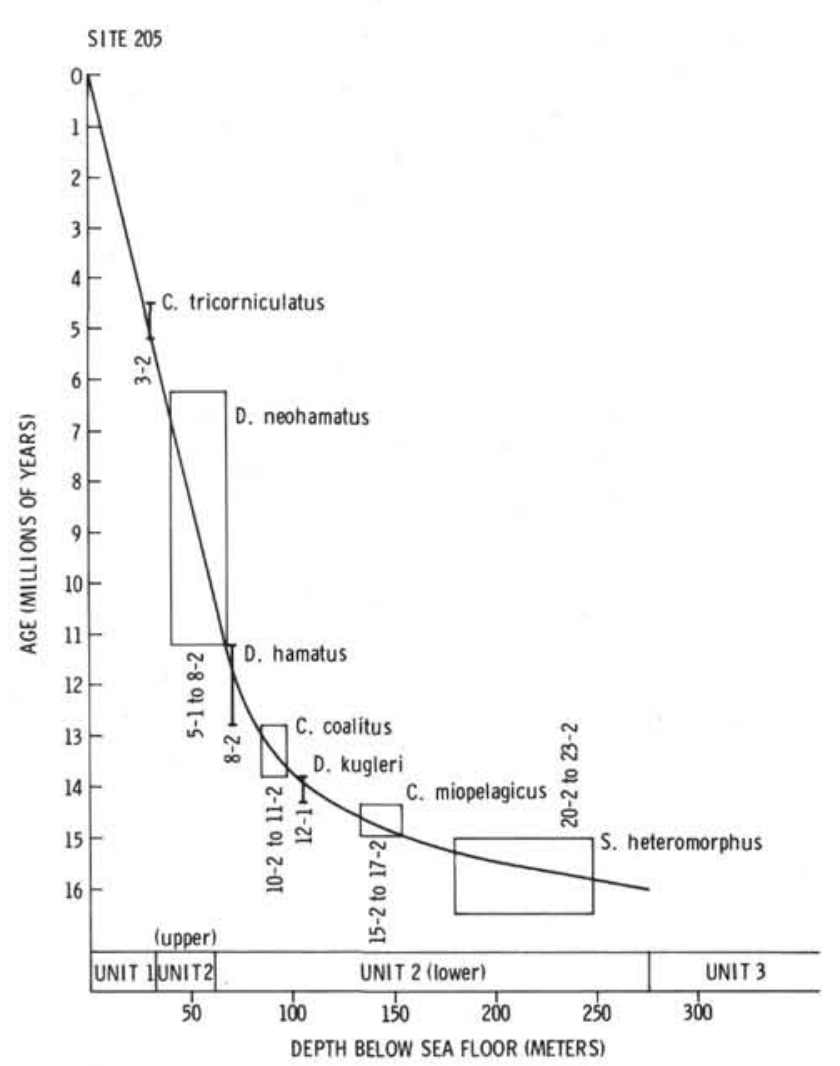

Figure 5. Sediment accumulation curve for Site 205.

two sites has been achieved by reading off ages of the cores taken at various depths from the sediment accumulation curves. The sediment accumulation rates for selected time intervals are given in Table 1.

Insofar as the sediment accumulation curves can be defined in this way, they both show a steady increase in sedimentation rate with depth without any strong inflection points. The initial rates of deposition at both sites are very high and difficult to estimate precisely. At Site 285 it could have been in excess of $500 \mathrm{~m} / \mathrm{m}$.y. and at Site 205 in excess of $150 \mathrm{~m} / \mathrm{m} . \mathrm{y}$. These rates have declined to 4 to $6 \mathrm{~m} / \mathrm{m} . \mathrm{y}$. for the last $5 \mathrm{~m} . \mathrm{y}$.

The sedimentation rates presented here are calculated on bases different from those in the site reports (this volume), in which sediment compaction was taken into account and different time scales were used. However, the same relative ages of cores are correct. These scales were not available at the time of writing. The sparcity of porosity data on Site 205 sediments render calculations based on uncompacted sediment very unreliable.

Units 1 and 2 at Site 285, a red clay unit overlying a nanno ooze, are comparable to Unit 1 at Site 205, a red clay with downward-increasing biogenic content. The ages of the bases of the units are found from the sediment accumulation curves to be 5.4 m.y., i.e., near the top of the late Miocene, at both sites.

Unit 3 at Site 285 , a nanno ooze with minor volcaniclastic contributions, is roughly comparable to the top few cores of Unit 2 at Site 205, essentially a glass shardrich nanno ooze to nanno-rich glass shard ash. A litho- logical transition to coarser grained nanno-bearing ash in Unit 2 at Site 205 is observed at a depth of 61 meters in the middle of Core 7, Section 4, and at about this level the proportion of biogenic material decreases downward significantly. The date of this change at Site 205 is $10.3 \mathrm{~m} . \mathrm{y}$. as compared to the age of $11.6 \mathrm{~m} . \mathrm{y}$. for the estimated base of Unit 3 at Site 285. However, the base of Unit 3 is not sampled, and the arbitrary depth of 74 meters assigned to it may be too deep.

Unit 4 at Site 285 , a clastic sequence with varying biogenic components, is comparable to the remainder of Unit 2 at Site 205. Both these units extend in age back to 15 to 16 m.y. near the base of the middle Miocene.

The Pliocene to Recent sediments are of equivalent thicknesses at both sites: about 22 meters at Site 285 (Units 1 and 2) and 30 meters at Site 205 (Unit 1). The accumulation of late Miocene sediments was almost identical at both sites: 37 meters at Site 205 and 38 meters at Site 285. However, in the middle Miocene the differences were very great: 209 meters at Site 205 and 505 meters at Site 285.

Apart from differences in the sedimentation rates (Table 1), there are other differences between the sediments at both sites, particularly those of volcaniclastic origin. For instance, clastic rhythms occur in the lower part of Unit 4 at Site 285 , but the only sedimentary structures recorded in the clastics at Site 205 are minor cross-laminations. Grain sizes are generally greater at Site 205 than at Site 285 (Table 2).

Reworking of sediments in the region during the middle and late Miocene is evidenced by sporadic appearances of pre-middle Miocene faunas in both sections, and the admixing of both deep- and shallow-water benthonic forams. There are generally lower proportions of shallow-water forams at Site 285 , suggesting that this site has been further removed from littoral environments, and the presence of large amounts of fragmented nannofossil debris at this site also suggests considerable transport of much of the material.

The evidence for turbidity current deposition at Site 285 , the generally finer grain sizes, the fragmented nannofossil material, and the relatively lower proportions of shallow-water forams all lead to the conclusion that sediment transport distances were considerably greater for Site 285 than for Site 205.

Comparison of the X-ray data (Site 205, Burns, Andrews et al., 1973; Site 285 Report, this volume) reveals no significant differences in the proportions of clastic minerals between the two sites. Plagioclase content, for example, is generally consistent. There is the same sharp decrease in augite content at both sites at about 15-15.5 m.y., i.e., below Core 205-17 and below Core 285A-4 (ages derived from sediment accumulation curves; Figures 5 and 6).

Carbonate content percentages are generally higher at Site 285 than at Site 205 for the late Miocene section (Table 3). This difference is reflected in Unit 3 at Site 285 and the top of Unit 2 at Site 250, in the proportions of clastic and biogenic material. It would appear that the biogenic material at Site 205 has been diluted by clastic material to a greater extent than that at Site 285, and this may be taken as further evidence that Site 205 is 


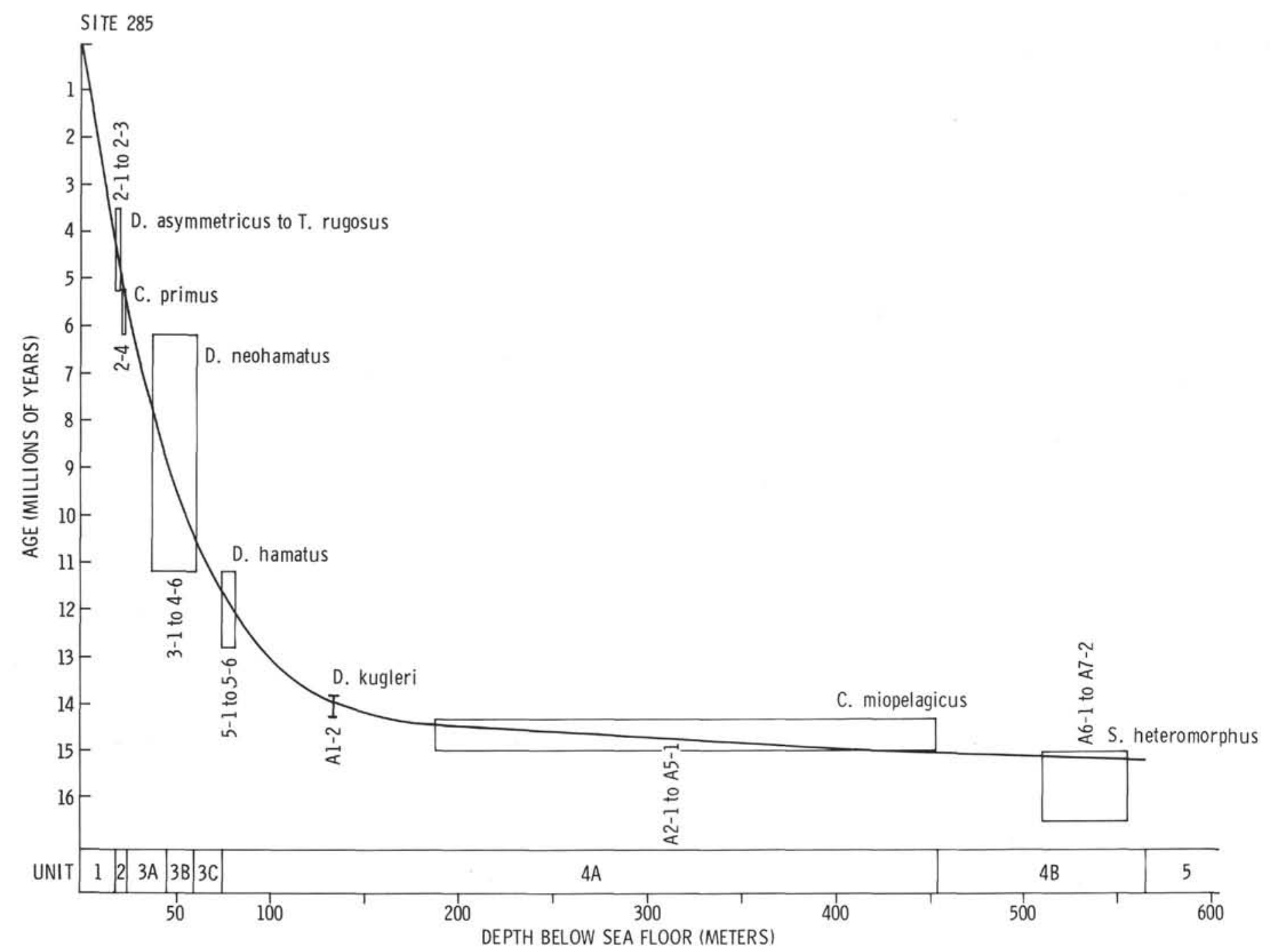

Figure 6. Sediment accumulation curve for Site 285. Lithologic units used are shipboard subdivisions. Subunits in Unit 3 have been subsequently eliminated and the Unit 3-Unit 4 boundary is raised slightly.

TABLE 1

Sedimentation Rates Derived From Sediment Accumulation Curves

\begin{tabular}{lrr}
\hline & Site 205 & \multicolumn{1}{c}{ Site 285} \\
\hline Pleiocene and Pleistocene (0-5 m.y.) & $6 \mathrm{~m} / \mathrm{m} . \mathrm{y}$. & $4 \mathrm{~m} / \mathrm{m} . \mathrm{y}$. \\
Late Miocene (5-10.5 m.y.) & $6 \mathrm{~m} / \mathrm{m} . \mathrm{y}$. & $7 \mathrm{~m} / \mathrm{m} . \mathrm{y}$. \\
Middle Miocene (10.5-16 m.y.) & $40 \mathrm{~m} / \mathrm{m} . \mathrm{y}$. & $100 \mathrm{~m} / \mathrm{m} . \mathrm{y}$. \\
\hline
\end{tabular}

closer to the sediment source. Some of the fine biogenic material at Site 285 appears to be redeposited as indicated above.

The refractive indexes of the volcanic glass detritus throughout both sequences show it to be generally acid to acid intermediate in composition (see Table 4). Refractive indexes are generally low, less than 1.54 and often less than 1.52 . Vesicularity, characteristic of highly viscous acid lavas, is very high. However, during the middle Miocene and lower late Miocene there are vary- ing influxes of basic and basic intermediate glasses at both sites, for example, in samples from Samples 11-3, $102 \mathrm{~cm}: 8-3,137 \mathrm{~cm}$; and $6-3,48 \mathrm{~cm}$ at Site 205 and in Sample 1-1, $105 \mathrm{~cm}$ in Hole 285A. A major influx at both sites is represented in Sections 285A-1-1 and 205$11-3$ at an age, calculated from the sedimentation rate curves, of 13.7 to 13.9 m.y.

Morphologically the basic and basic-intermediate glasses are similar at the two sites. Smoky or colored equant shards with low vesicularity (low vesicule density), thick vesicule walls, and common inclusions (generally pyroxenes) are dominant. Examples of these morphological types are shown in Plate 3. The grain sizes of these shards are generally larger at Site 205 than at Site 285 (compare Figures 1 and 2 of Plate 3 ) which is consistent with results quoted earlier (Table 2).

There are three distinctive morphological types of acid and acid-intermediate glasses at both sites (see Plate 2):

1) Pumice, with fine vesicules and a very high vesicular density. 
TABLE 2

Grain-Size Determinations for Samples From Sites 205 and 285

\begin{tabular}{|c|c|c|c|c|c|c|c|c|}
\hline & $\begin{array}{c}\text { Age } \\
\text { (m.y.) }\end{array}$ & $\begin{array}{c}\text { Sample } \\
\text { (Interval in } \mathrm{cm} \text { ) }\end{array}$ & $\begin{array}{l}\text { Depth } \\
(\mathrm{m})\end{array}$ & $\begin{array}{c}\text { Sand } \\
(\%)\end{array}$ & $\begin{array}{l}\text { Silt } \\
(\%)\end{array}$ & $\begin{array}{r}\text { Clay } \\
(\%)\end{array}$ & Classification & $\begin{array}{c}\text { Stratigraphic } \\
\text { Unit }\end{array}$ \\
\hline & \multicolumn{8}{|c|}{ Site 205} \\
\hline Plio. & 4.4 & $3-\mathrm{CC}$ & 27.0 & 0.5 & 34.5 & 65.0 & Silty clay & 1 \\
\hline $\begin{array}{l}\text { L. } \\
\text { Mio. }\end{array}$ & $\begin{array}{r}6.6 \\
7.7 \\
8.3 \\
10.8\end{array}$ & $\begin{array}{l}5-1,90 \\
5-6,103 \\
6-2,110 \\
7, C \text { C }\end{array}$ & $\begin{array}{l}38.9 \\
46.5 \\
49.6 \\
65.0\end{array}$ & $\begin{array}{r}36.3 \\
0.4 \\
59.3 \\
6.3\end{array}$ & $\begin{array}{l}50.2 \\
82.4 \\
28.3 \\
68.4\end{array}$ & $\begin{array}{l}13.5 \\
17.2 \\
12.4 \\
25.3\end{array}$ & $\begin{array}{l}\text { Sandy silt } \\
\text { Silt } \\
\text { Silty sand } \\
\text { Clayey silt }\end{array}$ & 2 (upper) \\
\hline $\begin{array}{l}\text { M. } \\
\text { Mio. }\end{array}$ & $\begin{array}{l}11.3 \\
12.1 \\
14.7 \\
15.8\end{array}$ & $\begin{array}{l}8-3,13 \\
8, \mathrm{CC} \\
15, \mathrm{CC} \\
23, \mathrm{CC}\end{array}$ & $\begin{array}{r}68.1 \\
74.0 \\
140.0 \\
155.0\end{array}$ & $\begin{array}{r}84.9 \\
79.0 \\
0.1 \\
0.6\end{array}$ & $\begin{array}{r}9.3 \\
15.6 \\
69.5 \\
30.0\end{array}$ & $\begin{array}{r}5.8 \\
5.4 \\
30.3 \\
69.4\end{array}$ & $\begin{array}{l}\text { Sand } \\
\text { Sand } \\
\text { Clayey silt } \\
\text { Silty clay }\end{array}$ & 2 (lower) \\
\hline & \multicolumn{8}{|c|}{ Site 285} \\
\hline Pleist. & ca 1 & $1-3,80$ & 3.8 & 0.0 & 37.8 & 62.2 & Silty clay & 1 \\
\hline & $\begin{array}{l}10.6 \\
10.6 \\
11.7\end{array}$ & $\begin{array}{l}4-3,110 \\
4-4,61 \\
5-1,81\end{array}$ & $\begin{array}{l}59.1 \\
60.1 \\
74.8\end{array}$ & $\begin{array}{l}0.0 \\
0.0 \\
0.0\end{array}$ & $\begin{array}{l}50.6 \\
52.0 \\
55.2\end{array}$ & $\begin{array}{l}49.4 \\
48.0 \\
44.8\end{array}$ & $\begin{array}{l}\text { Clayey silt } \\
\text { Clayey silt } \\
\text { Clayey silt }\end{array}$ & $3 \mathrm{C}$ \\
\hline $\begin{array}{l}\text { Mid } \\
\text { Mio. }\end{array}$ & $\begin{array}{l}12.2 \\
13.8 \\
13.9 \\
15.1\end{array}$ & $\begin{array}{l}5-6,96 \\
1 A-1,67 \\
1 A-2,60 \\
6 A-3,23\end{array}$ & $\begin{array}{r}82.5 \\
131.7 \\
133.1 \\
513.2\end{array}$ & $\begin{array}{l}2.2 \\
0.1 \\
0.3 \\
0.1\end{array}$ & $\begin{array}{l}54.4 \\
44.3 \\
66.7 \\
42.8\end{array}$ & $\begin{array}{l}43.4 \\
55.7 \\
33.0 \\
57.1\end{array}$ & $\begin{array}{l}\text { Clayey silt } \\
\text { Silty clay } \\
\text { Clayey silt } \\
\text { Silty clay }\end{array}$ & $\begin{array}{l}4 B \\
4 C\end{array}$ \\
\hline
\end{tabular}

TABLE 3

Carbonate Content of Samples From Sites 205 and 285

\begin{tabular}{|c|c|c|c|c|c|}
\hline & $\begin{array}{l}\text { Age } \\
\text { (m.y.) }\end{array}$ & $\begin{array}{c}\text { Sample } \\
\text { (Interval in } \mathrm{cm} \text { ) }\end{array}$ & $\begin{array}{l}\text { Depth } \\
\text { (m) }\end{array}$ & $\begin{array}{c}\mathrm{CaCO}_{3} \\
(\%)\end{array}$ & $\begin{array}{l}\text { Stratigraphic } \\
\text { Unit }\end{array}$ \\
\hline & \multicolumn{5}{|c|}{ Site 205} \\
\hline \multirow{2}{*}{$\begin{array}{l}\text { Plio. } \\
\text { L. } \\
\text { Mio. }\end{array}$} & 3.4 & $3-2,137$ & 20.9 & 44 & \multirow[t]{2}{*}{1} \\
\hline & 7.2 & $5-3,120$ & 42.2 & 10 & \\
\hline \multirow{3}{*}{$\begin{array}{l}\text { M. } \\
\text { Mio. }\end{array}$} & 9.2 & $6-6,80$ & 55.3 & 23 & 2 (upper) \\
\hline & $\begin{array}{l}12.9 \\
15.8\end{array}$ & $\begin{array}{l}9-7,0 \\
23, \mathrm{CC}\end{array}$ & $\begin{array}{r}83.0 \\
255.5\end{array}$ & $\begin{array}{r}5 \\
16\end{array}$ & 2 (lower) \\
\hline & \multicolumn{5}{|c|}{ Site 285} \\
\hline \multirow{4}{*}{ Plio. } & 4.4 & $2-1,138$ & 18.4 & 75 & \multirow[t]{2}{*}{1} \\
\hline & 4.8 & $2-3,86$ & 20.9 & 62 & \\
\hline & 5.2 & $2-4,61$ & 22.1 & 75 & \multirow[t]{2}{*}{2} \\
\hline & 5.4 & $2-5,131$ & 24.3 & 64 & \\
\hline L. & 7.0 & $3-2,90$ & 38.4 & 64 & \multirow{2}{*}{$3 \mathrm{~A}$} \\
\hline \multirow[t]{4}{*}{ Mio. } & 8.5 & $3-5,60$ & 42.6 & 64 & \\
\hline & 10.0 & $4-1,107$ & 56.1 & 54 & $3 \mathrm{~B}$ \\
\hline & 10.4 & $4-4,50$ & 60.0 & 44 & \multirow[t]{2}{*}{$3 \mathrm{C}$} \\
\hline & 10.7 & $4-6,40$ & 62.9 & 16 & \\
\hline M. & 11.9 & $5-4,80$ & 79.3 & 14 & \multirow[t]{2}{*}{$4 \mathrm{~A}$} \\
\hline \multirow[t]{2}{*}{ Mio. } & 13.9 & $1 \mathrm{~A}-2,64$ & 133.1 & 11 & \\
\hline & 15.0 & $5 \mathrm{~A}-2,81$ & 455.3 & 6 & $4 B$ \\
\hline
\end{tabular}

2) Thin, platy, and angular broken shards with moderately thick vesicule walls, resulting from the breakup of glass with large, high-density vesicules.

3) Shards with a high density of elongated "pipe" vesicules.

Finely vesicular pumice is more common at Site 205 than at Site 285. This is evidence of a higher proportion of ash-fall deposition at Site 205 from a more local source.

In Sample 205-2, CC is an occurrence of basic and basic-intermediate glass with refractive indexes greater than 1.56 , which possibly represents only a minor basic volcanic event, or only a minor sediment contribution of a basic source to this site, as the cores examined above and below this core are dominated by acid pumiceous glasses. This event can possibly be related to the basic volcanism on the Lau Ridge represented by the basic material found at Site 203 in the Lau Trough in the Pliocene to Pleistocene section (Churkin and Packham, 1973). This basic glass is not evident in the samples available from Site 285, but sampling is incomplete.

The sequence of lithologies and the variation of clastic components with time are essentially the same for both sites, and it therefore appears that the two sites, both 
TABLE 4

Composition of Glass Shards in Samples From Sites 205 and 285

\begin{tabular}{|c|c|c|c|c|c|c|c|}
\hline & \multirow{2}{*}{$\begin{array}{l}\text { Age } \\
\text { (m.y.) }\end{array}$} & \multirow{2}{*}{$\begin{array}{c}\text { Sample } \\
\text { (Interval in } \mathrm{cm} \text { ) }\end{array}$} & \multirow{2}{*}{$\begin{array}{l}\text { Depth } \\
\text { (m) }\end{array}$} & \multicolumn{4}{|c|}{$\begin{array}{c}\text { Proportions of Glass Types } \\
\text { (5-fold scale) }\end{array}$} \\
\hline & & & & Acid & A.I. & B.I. & Basic \\
\hline & Site 205 & & & & & & \\
\hline Plio. & $\begin{array}{l}1.8 \\
2.4\end{array}$ & $\begin{array}{l}2-2,86 \\
2-4,30\end{array}$ & $\begin{array}{l}11 \\
14\end{array}$ & $\begin{array}{l}5 \\
5\end{array}$ & & & \\
\hline $\begin{array}{l}\text { L. } \\
\text { Mio. }\end{array}$ & $\begin{array}{l}7.9 \\
8.1 \\
8.2 \\
9.6\end{array}$ & $\begin{array}{l}5-6,121 \\
6-2138 \\
6-3,48 \\
7-1,81\end{array}$ & $\begin{array}{l}47 \\
49 \\
50 \\
57\end{array}$ & $\begin{array}{l}1 \\
2 \\
\operatorname{tr} \\
1\end{array}$ & $\begin{array}{l}4 \\
3 \\
1 \\
1\end{array}$ & $\begin{array}{l}\mathrm{tr} \\
\mathrm{tr} \\
4 \\
3\end{array}$ & $\begin{array}{l}\operatorname{tr} \\
\operatorname{tr}\end{array}$ \\
\hline $\begin{array}{l}\text { M. } \\
\text { Mio. }\end{array}$ & $\begin{array}{l}10.6 \\
11.2 \\
11.6 \\
13.0 \\
\text { do } \\
13.4 \\
13.6 \\
13.7 \\
14.6 \\
15.2\end{array}$ & $\begin{array}{l}7-5,75 \\
8-2, \text { top } \\
8-3,137 \\
10-1,76 \\
10-1,136 \\
10, \text { CC } \\
11-1,145 \\
11-3,102 \\
15-3,130 \\
20-2,130\end{array}$ & $\begin{array}{r}63 \\
67 \\
69 \\
84 \\
84 \\
92 \\
96 \\
98 \\
134 \\
181\end{array}$ & $\begin{array}{l}2 \\
3 \\
\\
\operatorname{tr} \\
\text { tr } \\
\text { tr } \\
\text { tr } \\
\text { tr } \\
4 \\
1\end{array}$ & $\begin{array}{l}3 \\
2 \\
1 \\
4 \\
3 \\
4 \\
3 \\
2 \\
1 \\
4\end{array}$ & $\begin{array}{l}4 \\
2 \\
2 \\
1 \\
2 \\
2 \\
\text { tr } \\
\text { tr }\end{array}$ & tr \\
\hline & Site 28 & & & & & & \\
\hline $\begin{array}{l}\text { Pleist. } \\
\text { Plio. }\end{array}$ & 1.4 & $1-6,41$ & 7 & 5 & & & \\
\hline $\begin{array}{l}\text { L. } \\
\text { Mio. }\end{array}$ & $\begin{array}{r}7.0 \\
10.2\end{array}$ & $\begin{array}{l}3-2,46 \\
4-2,80\end{array}$ & $\begin{array}{l}38 \\
57\end{array}$ & $\begin{array}{l}4 \\
1\end{array}$ & $\begin{array}{l}1 \\
4\end{array}$ & $\mathrm{tr}$ & \\
\hline $\begin{array}{l}\text { M. } \\
\text { Mio. }\end{array}$ & $\begin{array}{l}11.7 \\
13.9 \\
14.4 \\
14.6 \\
14.8 \\
15.0 \\
15.05 \\
15.1\end{array}$ & $\begin{array}{l}5-1,81 \\
1 \mathrm{~A}-1,105 \\
2 \mathrm{~A}-1,24 \\
3 \mathrm{~A}, \mathrm{CC} \\
4 \mathrm{~A}, \mathrm{CC} \\
5 \mathrm{~A}-2,140 \\
6 \mathrm{~A}-2,26 \\
7 \mathrm{~A}-1,61\end{array}$ & $\begin{array}{r}75 \\
132 \\
187 \\
254 \\
358 \\
456 \\
512 \\
556\end{array}$ & $\begin{array}{l}1 \\
1 \\
\text { tr } \\
1 \\
1 \\
4 \\
3 \\
4\end{array}$ & $\begin{array}{l}4 \\
1 \\
3 \\
3 \\
4 \\
1 \\
2 \\
1\end{array}$ & $\begin{array}{l}\operatorname{tr} \\
3 \\
2 \\
1\end{array}$ & tr \\
\hline
\end{tabular}

Note: Composition is deduced from the refractive indices using the following: R.I. $<1.52$ - Acid; $1.52<$ R.I. $<1.54$ - Acid-intermediate; $1.54<$ R.I. $<1.57$ - Basic-intermediate; $1.57<$ R.I. - Basic.

situated in the sediment accumulated on the Minerva Abyssal Plain, are within the same sediment pile. The source area for the volcaniclastic components is the same for both sites, apparently the Lau Ridge. Earlier suggestions that the Three Kings Rise acted as a source for sediment at Site 285 must be discounted on lithologic grounds except for very minor contributions. Evidence from the seismic profiles is also contrary to the view that it was an important sediment source (see below). The general westerly slope of the South Fiji Basin revealed by the bathymetric map adds support to the argument for considerable turbidity current transport from the Lau Ridge to Site 285. Examination of abstracts of the World Sediment Data Tape held at Scripps Institution of Oceanography reveals that although volcanic detritus occurs in samples from the Kermadec Trench-Ridge area, the Lau-Havre Trough, the Lau-Colville ridge area, the Kupe and Minerva Abyssal plains, the Hunter Fracture Zone area, and adjacent to the New Zealand Continent, none is recorded in samples from the Three Kings Rise or its flanks.

\section{SEISMIC PROFILES AND STRUCTURAL FEATURES}

A limited number of seismic profiles are available for study, their location is indicated in Figure 1. The bathymetric regions outlined previously will be discussed in turn.

\section{Lau-Colville Ridge}

Some geological data are available as a result of geological mapping of islands of the Lau Group at the northern end of the Lau Ridge by Ladd and Hoffmeister (1945). The sequence comprises the Andesitic Lau Volcanics that underlie bedded shallow-water late Miocene Futuna Limestone. Gill and McDougall (1973) Gill and Gorton (1973) have dated samples of the volcanics at 7.5 to 9.0 m.y. Then follows a basaltic volcanic unit, the Koro Mbasansa Volcanics, which is in turn overlain by Pliocene Ndalithoni Limestone, another shallow-water limestone. Pleistocene Frelanga Limestone (reef) is succeeded on a few islands by Mango Basalt. 
Significantly older rocks have been found on the Tonga Ridge. On the Island of Eua at $21^{\circ} 25^{\prime} \mathrm{S}$ late Eocene shallow-water limestone rests on volcanics (Hoffmeister, 1932; Stearns, 1971). The volcanics comprise lava, agglomerate, conglomerate, and tuff. Ewart and Bryan (1972) record high-alumina tholeiite, basaltic andesite, quartz gabbro, olivine basalt, and dacite tuff. Pre-limestone dykes of acid andesite cut the volcanics. The same authors conclude that the volcanic suite represents a very early stage of island arc development similar in many respects to ocean floor lavas.

Four profiles across the Lau-Colville ridge are illustrated on Plate 4. Interpretations of four additional lines are illustrated by Karig (1970b).

In the profiles, the ridge crest is smooth, but as Karig points out there is no concrete evidence that the crest was all at wavebase. Ladd and Hoffmeister (1945) suggested that the Lau Islands represent a series of volcanic centers developed on the ridge. The dating of the limestone formation overlying the Lau Volcanics as late Miocene, and the radiometric dates suggest that the older parts of the Lau Volcanics and their possible southern extension along the Lau Ridge to at least $31^{\circ} 31^{\prime} \mathrm{S}$ could well have been the source of the volcaniclastic sediment on the Minerva Abyssal Plain and a contributing source of sediment on the Kupe Abyssal Plain.

The Lau-Colville Ridge is asymmetrical in most profiles, with the steeper flank on the east. This flank is commonly step faulted down into the Lau-Havre Trough. The normal faulted terraces are usually covered by sediments that probably accumulated in the early stages of rifting. Their westward limit is below the ridge crest, and sediments thicken eastwards reaching a maximum thickness of around 300 meters at the western edge of the Lau-Havre Trough.

The asymmetry of the ridge crest region is emphasized by the long slope from the break of slope below of the ridge crest region to the South Fiji Basin proper. The sediment on this slope is usually 200-600 meters thick, being significantly greater than on the eastern flank. The sediment shows ponding behind ridges on the flank in subsidiary basins. On the steepest sediment-covered slope, immediately below the break of slope below the ridge crest, there is slumping in several of the profiles (Plate 4, Profile D). Step faulting is seen on the lower part of the slope in Plate 4, Profile C. The ridges that form the ponds on the western flank of the ridge trend in a direction inclined to that of the ridge crest.

Probable intrusions, such as on Plate 4, Profile A, appear to have sediments ponded against them and are therefore likely to be of Miocene or older age, if the sediment accumulated against them is the result of middle to late Miocene volcanism on the ridge crest. Accepting the rifting origin of the Lau-Havre Trough suggested by Karig (1970b) and supported by drilling at Site 203 (Burns, Andrews, et al., 1973), these ridges then could be part of the original volcanic arc on which the Miocene volcanic arc was superimposed. Some of the sediment on the flanks may date back to the late Eocene if the age of the basal sediments on Eua are indicative of the date of formation of the prerift Lau-Tonga Ridge. If the South Fiji Basin was formed by asymmetrical sea- floor spreading the flank ridge may represent an extinct spreading center.

If the Fiji Islands are considered as a northern extension of the Lau Ridge, then it is likely that the basement of the ridge may have developed at the same time. In the account given by Rodda (1967) the oldest volcanic phase is late Eocene to early Oligocene (older Wainimala Group). There is no record of further activity until the latest Oligocene to early Miocene. The volcanics of this stage are regarded by Gill and Gorton (1973) as representative of the early stage of evolution of the arc. Shallow-water limestones and clastic sediments occur in both the older and younger Wainimala Groups. A second volcanic period with typical island arc characteristics (Gill, 1970) extends from late Miocene into the Pliocene. The status of supposed middle Miocene rocks on Fiji is in doubt (Gill and McDougall, 1973). A third phase of volcanism that includes shoshonites commenced in the Pliocene. Gill and Gorton interpret the geochemical data as indicative of the location of a subduction zone to the northeast of Fiji from the Eocene to the beginning of the Pliocene. Then with the formation of the Lau-Havre trough and the dispersal of the arc comprising Fiji and the New Hebrides, volcanism on Fiji became shoshonitic and basaltic. It will be noted at this point that the history of Fiji differs from that inferred for the Lau Ridge from deep-sea drilling in that the major influx of sediment in the middle Miocene does not clearly correspond to a strongly volcanic phase on Fiji. In fact it appears that this was an interval of deformation and plutonic intrusion (Rodda et al., 1967).

\section{New Zealand Slope}

Only one profile across this feature is available (Plate 5, Profile A). This profile illustrates the shelf, the Northland Marginal Plateau, and abyssal plain. The first two are separated by the Vening Meinesz Fracture Zone scarp, and the latter by a steep lower slope passing into a rise. The sediment on the plateau thins towards its seaward edge where the magnetic profile (Figure 7) suggests that continental crust ends. The sediment is disturbed, displaying folding that may be a combination of faulting and slumping. The main scarp on the "fracture zone" is about 1000 meters, a smaller upper scarp is about 300 meters. Only minor sediment progradation on the shelf edge has occurred subsequent to the faulting, and the disturbed deposits on the marginal plateau are overlain unconformably by less than 50 meters of sediment. It is therefore inferred that the sediment of the rise and the Kupe Abyssal Plain are at least in part contemporaneous with the sediments of the plateau and that their deposition has been followed by deformation and minor progradation. At first sight, the most likely event to have caused the deformation is the Kaikoura Orogeny which has been dated in the Northland region as middle Miocene to early Pliocene, between the limits of 16 and $4.3 \mathrm{~m} . y$., also according to Stipp and Thompson (1971). However, the relatively small amount of postdeformation sedimentation (seen on the profile) implies that the supply has been substantially reduced since the deformation took place and should postdate the major episode of calcalkaline volcanism that occurs in 


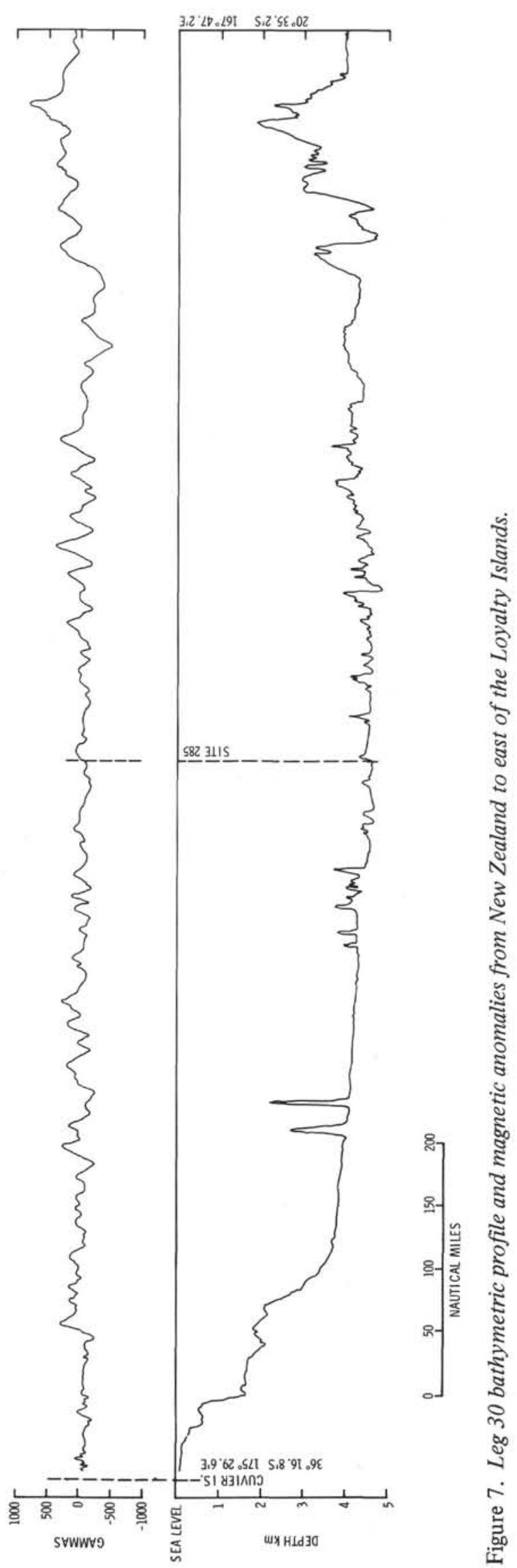

the region. In Northland this volcanism is late early Miocene to middle Miocene. Subsequent volcanism was largely basaltic (Stipp and Thompson, 1971). A late Miocene date for deformation is probably too old, since on the Coromandel Peninsula, where the illustrated profile starts, andesitic and rhyolitic volcanism continued into the upper Miocene and Pliocene with a few small volcanic centers in the Pleistocene (Thompson, 1960; Scholfiedl, 1967). In view of this continued sediment supply, it is more likely that the deformation of the Northland Marginal Plateau occurred later than in Northland, i.e., late in the Pliocene after most of the volcanism had ceased, and the progradation took place in the Pleistocene. This argument however requires very rapid subsidence, much too rapid to be explained by contraction of the lithosphere due to cooling.

The timing of events outlined above differs from that put forward by Karig (1970b) who suggested that activity on the Vening Meinesz Fracture Zone ceased prior to the commencement of formation of the Lau-Havre Trough (about the Miocene-Pliocene boundary).

The wedge of sediment on the Northland Marginal Plateau probably accumulated as a progradating sequence on the edge of the shelf passing oceanwards into the thinner slope sequence. The subsidence of the outer shelf to form the rough marginal plateau probably took place in the Pliocene and was followed by progradation at the new continental shelf margin and the disturbed sediment of the plateau has been covered by hemipelagic deposits. The "Vening Meinesz Fracture Zone" then, occurs well within the outer limit of continental crust.

\section{Three Kings Rise}

Profiles across this feature (Plate 6, Profiles A and B) indicate that the basement is irregular, and it is covered by an irregular layer of seismically transparent sediment that reaches about 600 meters in thickness. It is presumed that the sediment is biogenic ooze and if so would have started to accumulate early in the Tertiary. Although some seamounts occur on the rise, it is not likely to have been a significant source of sediments for the South Fiji Basin.

\section{South Fiji Basin}

\section{Kupe Abyssal Plain}

The sediment wedge of this abyssal plain thins from the foot of the rise north of New Zealand towards the north (Plate 5). The maximum thickness is over 1000 meters (1.1 sec two-way time) thinning to around 300 meters ( $0.4 \mathrm{sec}$ two-way time) (Figure 8 ). The basement is irregular. In the north-south profile, the basement has ridges and basins with an amplitude of 500 to 1000 meters and a wavelength of 30 to $60 \mathrm{~km}$. The basement is deepest in the center of the abyssal plain and rises above the sediment surface to the north to form a barrier that prevents all but a minor proportion of the sediment moving northward (Plates 5 and 7, Profiles B and C).

The sediment column has many seismic reflectors and is almost certainly clastic. The steady downslope from 
the base of the New Zealand slope and the distribution of sediment thicknesses suggest that New Zealand was the principal source of sediment (Plate 5). The Lau Ridge probably also made some contribution, but it is a less-significant feature in the south than in the north and is a much smaller area than New Zealand.

Profile A on Plate 7 shows a gentle bulge in the sediment surface in the central part of the basin. This is also reflected on the contour map where a shallow tongue extends northward from New Zealand. This evidence supports the concept of a predominantly southern source of sediment. The sediment in this abyssal plain is most likely to be Miocene volcaniclastic sediments derived from New Zealand and to a lesser extent, the Lau Ridge.

The surface of the Kupe Abyssal Plain is generally regular, showing no signs of deformation. In the lower part of the plain in the north-south profile there are several channels. However, minor disturbance is visible not far below the surface. An unconformity is developed at a depth of about $0.1 \mathrm{sec}$. This also corresponds to the time at which two tall seamounts on the same profile were formed.

In the northeastern corner of the abyssal plain it appears that the Lau Ridge sediments underlie the Kupe Abyssal Plain (Plate 4, Profile C) while in the profile to the south (Plate 4, Profile D) the Lau sediments appear to be ponded by a high feature on the edge of the ridge flank and the abyssal plain sediments appear to abut against the feature.

\section{Minerva Abyssal Plain}

In the northern part of the South Fiji Basin, the second abyssal plain is separated from the Kupe Abyssal Plain to the south by a terrace-like extension of the Lau Ridge and a high basement ridge. Basement ridges projecting through the Minerva Abyssal plain become more evident to the west and northwest as the basin deepens. The abyssal plain is 4300 meters below sea level in the east, deepening to 4800 meters in the vicinity of Site 285 . The site lies in a depression in the plain in which the sediment column displays deformation, late in the depositional history (Plate 7, Profiles B and C). At the southern end of the depression, sediments from the Kupe Abyssal Plain have locally penetrated the northern barrier and spilled in over the Minerva Abyssal Plain sediments (Plate 7, Profiles B and C). The Minerva Abyssal Plain is bounded in the northwest by basement ridges that prevent sediment penetrations into depressions (Plate 6, Profile A). To the north, the sediment surface rises and is gently undulating with some zones of stronger deformation (Plate 6, Profile C). The deformation appears to be relatively recent and may be related to movement associated with the Hunter Fracture Zone. The surface of the abyssal plain becomes shallower and more irregular towards the northeastern corner of the basin.

The northeast-southwest Nova Expedition profile (Plate 6, Profile C) shows convergence of reflectors within the sediment column towards the southwest and increase in the strength of the near-surface reflectors. This is also true of the Leg 21 profile west of Site 205 (Plate 6, Profile B). The sediments become seismically

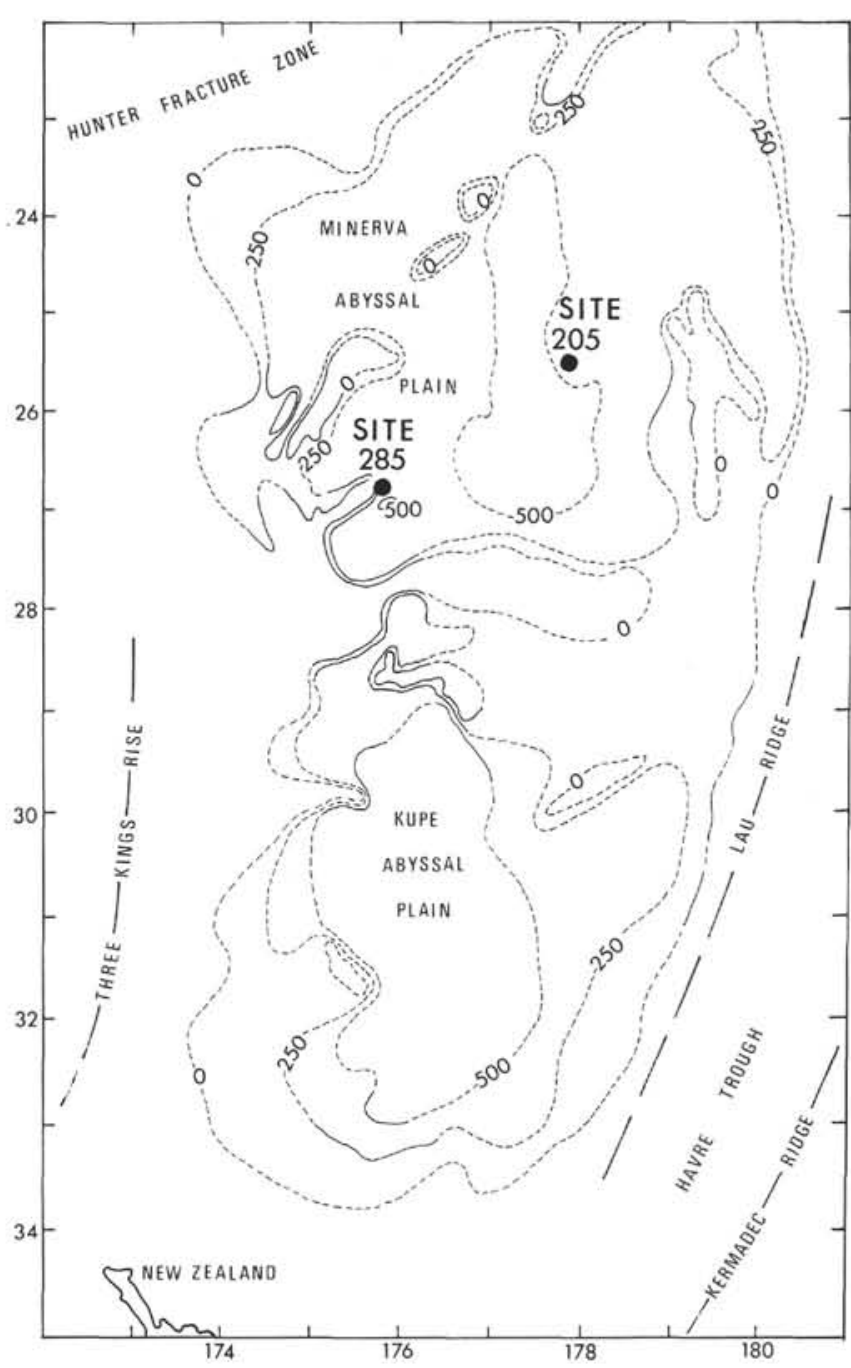

Figure 8. Isopach map of sediment thickness in the South Fiji Basin. The map attempts to summarize the clastic sediment distribution on the Kupe and Minerva Abyssal plains and on the western flank of the Lau Ridge. Control is based on the available seismic profiles and the bathymetry. Contours are highly conjectional in the north and west of the basin. Contours represent sediment thickness in meters.

more transparent again north of Site 285 . The sequence in the Minerva Abyssal Plain has been drilled at Sites 205 and 285 and the results discussed previously. Generally, the sediment has been shown to have an easterly provenance from the Lau Ridge (or more accurately, the combined Lau-Tonga Ridge) and was deposited in the mid to late Miocene. The disturbance of the sediment pile in the northern part of the abyssal plain probably took place after the end of the Miocene. The Oligocene part of the sequence penetrated at Site 205 is not readily identifiable on the profiles. On the sonobuoy record it appears to be seismically more transparent than the overlying volcaniclastic sequence, but since the volcaniclastic sequence at Site 285 also becomes more transparent downwards, interpretations 


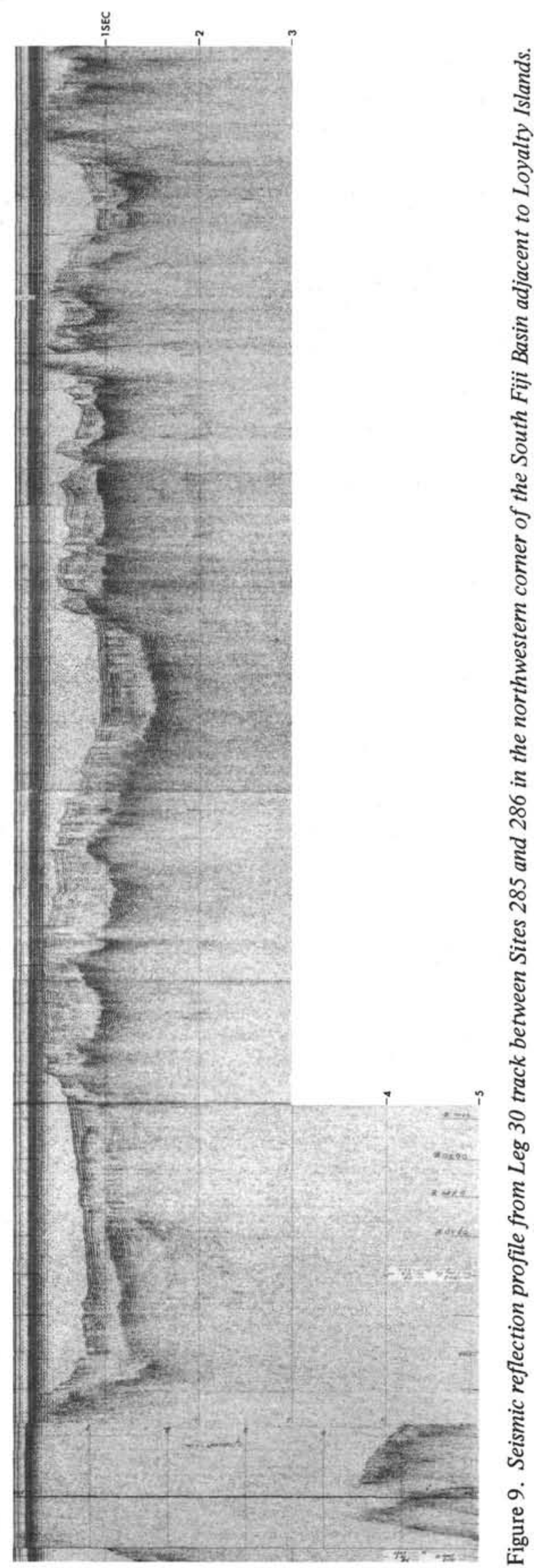

are ambiguous. The isopach map of the clastic sediment (Figure 8 ) reveals that the region of greatest thickness lies east of the center of the basin immediately to the west of Site 205. The area of maximum thickness is elongated parallel to the basin length.

The wavelength and amplitude of basement structures under the Minerva Abyssal Plain are similar to those under the Kupe Abyssal Plain. The basement ridges have a trend of $50^{\circ}$ to $70^{\circ}$, they are shallowest on the western side of the basin than the east. Unlike the Kupe Abyssal Plain basement, some of the basement features of the Minerva Abyssal Plain are fault bounded (Plate 6, Profiles A and C).

\section{Central Ridge}

The seismic profiles reveal this feature to be a region of rough topography with no significant sediment cover. It adjoins a westerly prolongation of the Lau Ridge that appears from the available soundings to have a smooth surface that is probably sediment covered, but no reflection profiles over it are available. The ridge separates the sediment of the two abyssal plain provinces.

\section{Ridge and Trough Province}

Towards the northwest, the basement rises irregularly out of the Minerva Abyssal Plain. Several fault scarps and grabens are apparent on the profile from Site 285 to Site 286 (Plate 6, Figures 7 and 9). The greater downthrows are generally on the northern sides of fault blocks. In simplified terms, these bound gently south tilted blocks. The south tilted blocks have short wavelength irregularities of 2 to 10 miles and an amplitude to 50 to 300 meters. The basement is overlain by a sequence of sediments that contains a number of seismic reflectors. The surface of the sediment parallels the basement irregularities and progressively thickens from less than 75 meters ( $0.1 \mathrm{sec}$ two-way time) north of Site 285 to over 500 meters ( $0.6 \mathrm{sec}$ two-way travel time) at $23^{\circ} 40^{\prime} \mathrm{S}$, $170^{\circ} 40^{\prime} \mathrm{E}$. To the northwest of this point the sediment thickens suddenly into an irregular depression 30 miles wide (Figure 9). The most likely interpretation of the seismic profile across this depression is that the greater part of the sequence on the ridge passes beneath later cover. The later sediment could have been derived from the adjacent Loyalty Islands. The disturbed surface of the sediment in this depression could be the result of tectonic activity associated with the South New Hebrides Trench that lies nearby to the east. Sediment infill is also found in two narrower depressions to the southeast on the same profile. Between there and the northwestern extremity of the Minerva Abyssal Plain, depressions contain no flat-lying sediment infill.

The southeasterly thinning wedge of sediment overlying the irregular basement in this province presents a problem. The sediment shows some irregularities in thickness, but does not have the appearance of having been deposited as a pelagic drape deposit over an irregular surface. The presence of a number of reflectors is suggestive of a clastic origin for the sequence (cf the seismically transparent succession on the Three Kings Rise). The thinning from north to south is too rapid to 
be explained by increase in age northwards or by differences in elevation relative to the carbonate compensation depth.

The most likely explanation is that the sediment was laid down on a relatively smooth sea floor as a clastic wedge derived from the north. The sea floor was disturbed by faulting and possibly minor folding, after which the middle and late Miocene clastic sediments of the Minerva Abyssal Plain were deposited (Plate 6, Profile A). The later sediment-fill in the north may have also been of similar or younger age. It has subsequently been deformed near the South New Hebrides Trench.

\section{HISTORY OF THE SOUTH FIJI BASIN}

The oldest terrain in the region is that of New Caledonia and the North Island of New Zealand. These two are connected by the Norfolk Ridge. The basement rocks of New Caledonia and northern New Zealand are late Paleozoic to Mesozoic graywackes deformed during the Rangatata Orogeny in the Mid Cretacous (Lillie and Brothers, 1970; Fleming, 1969). The Norfolk Ridge has a dislocation at its southern end where it meets the line of the "Vening Meinesz Fracture Zone." Since this fracture does not appear to intersect the Lord Howe Rise, it is likely to have initially developed during the formation of the New Caledonia Basin. The present expression of the "fracture zone" as a series of en echelon normal fault scarps at the edge of the New Zealand Continental Shelf is the result of vertical movement on the former (?) transform structure. The Norfolk Basin and other deep troughs between the Norfolk Ridge and the Three Kings Rise almost certainly contain oceanic crust (e.g., stations N22, 23, Shor et al., 1971). Oceanic crust is also represented by the ultramafic overthrusts in New Caledonia (Avias, 1967; Brothers and Blake, 1973). Sediments under the thrust sheet range up to the end of the Eocene and intrusives cutting both the sediment and the ultramafics are dated (Guillon and Routhier, 1971) at $33 \pm 3 \mathrm{~m} . \mathrm{y}$. (late early Oligocene). This dates the overthrusting as early Oligocene. The date of formation of this crust must be Eocene or older.

The middle to late Eocene thick volcanogenic sequences at Site 286 can be traced on the profile from Site 285 to 286 , from Site 286 to the southward thinning wedge in the northwestern part of the South Fiji Basin (Figure 7). Further, the sediments can be traced well up the steep flank of the Loyalty Island ridge without significant thinning. The implications of this are that the New Hebrides Basin and the South Fiji Basin are part of the same body of sea floor and that the Loyalty Islands were probably not the source of the volcanic detritus, having been uplifted later. Undoubtedly the islands were the source of the sediment infill described in the northwestern corner of the South Fiji Basin. Similar infills occur in the southern part of the New Hebrides Basin. Since all the volcanic rocks described from the early Tertiary of New Caledonia are tholeiitic basalts (Guillon and Routhier, 1971), New Caledonia could not have been a source of the sediment, because most of the detritus at Site 286 is intermediate to acid. The oldest fossiliferous rocks on the New Hebrides are early Miocene (Mitchell and Warden, 1971) and they have reached their present location in relatively recent time (Site 286, this volume; Chase, 1971). It is necessary then to look further afield for the source of the volcaniclastic sediments. It was pointed out that there were abundant Eocene volcanics on Fiji, they were also present in the Tonga Islands and volcanics of that age were likely to have formed the foundation on which the later ridge crest of the Lau Ridge was built in the Miocene. Further, if the older Lau-Tonga-Fiji arc is restored to a position prior to the formation of the South Fiji Basin, assuming no extension took place along the Lau Ridge the Western end of Fiji would lie adjacent to the truncation of the ridge on which New Caledonia and the Loyalty Islands lie. It was argued that the Eocene volcaniclastic sequence extended over the area of the Loyalty Islands. The ridge now forming the islands probably originated as an upfold in the oceanic crust perhaps with faulting and underthrusting on the western side as the oceanic crust was thrust over New Caledonia. Later volcanic activity is recorded on the ridge.

Evidence for deformation of the oceanic crust around Site 286 on a modest scale is clear. The sediments that cover the basement show considerable disturbance, and since they are largely turbidity current deposits, must have initially had a flat sheet-like disposition. This same argument is applied to the south thinning sediment wedge of the northwest South Fiji Basin.

The Eocene volcanogenic sediment then would have been deposited early in the history of the New HebridesSouth Fiji Basin when it was narrow and derived from a volcanic arc to the east. The north-south diminution of volcanic activity resulting from the geometry of plate motions at the time. Presumably, a trench lay on the outer side of the volcanic arc, and development of the new sea floor behind the arc and consequential forward migration of the arc occurred during the Eocene. The reason for the initiation of such an arc is not apparent. A hint that it may have been initially a rifted continental silver is given by the record by Stearns (1971) of red garnet and blue tourmaline in Eocene sediments on Eua (Tonga) and large granitic zenoliths in volcanics on the Kermadec Islands (Speight, 1910).

\section{Time and Mode of Formation of the South Fiji Basin Crust}

The history of the development of the crust of South Fiji Basin cannot be established on the present data. It does, however, appear that the following propositions should be taken into consideration is postulating a sequence of events.

1) The sea floor has an age of early late Oligocene (29-30 m.y.) at Site 205 on the eastern side of the basin.

2) The sea floor of the basin slopes generally to the west.

3) The age of the sea floor at Site 286 located on crust that probably is continuous with the South Fiji Basin and towards its western side is middle Eocene (47 m.y.).

4) The middle to late Eocene turbidite sequence at Site 286 can be traced with some confidence as a thinning wedge back into the South Fiji basin almost to Site 285 near the northern end of the Three Kings Rise.

4) The layering of the presumed turbidite sequence generally parallels the basement structure and has hence been tectonically disturbed.

6) In the western part of the Minerva Abyssal Plain basement hollows are filled with middle to late Miocene volcaniclastic sediments derived from the Lau Ridge 
and unconformably overlie the older disturbed presumed turbidite sequence.

7) Neither the older sequence nor deformation of the sea floor has been detected in the region of the Kupe Abyssal Plain (southern South Fiji Basin).

8) Oceanic crust occurs behind the Three Kings Rise in the Norfolk Basin.

It is suggested that the northwestern part of the South Fiji basin and its extension into the New Hebrides Basin is floored by older crust than the eastern and southern part of the South Fiji Basin. It is possible that the Three Kings Rise is a remnant arc segment, once continuous with the arc that formed the eastern boundary of the northern South Fiji Basin-New Hebrides Basin. If this is so, then the crust of the Norfolk Basin (between the Norfolk Ridge and the Three Kings Rise) would be of similar age to the northwestern South Fiji Basin-New Hebrides Basin and possibly the oceanic crust overthrust onto New Caledonia.

It is possible that spreading in the basin was discontinuous and relatively short lived, ending in the late Eocene when subduction on the outer side of the arc ceased. This cessation of subduction is postulated because of the rarity of early Oligocene island arch volcanics in the region. Plate motions were transferred to obduction, overthrusting sea floor onto New Caledonia. The sea floor of the New Hebrides Basin and the northwestern part of the South Fiji Basin (the only part formed at that time) were deformed as well. A second spreading phase may then have formed the crust in the eastern and southern parts of the South Fiji Basin, forming crust at Site 205 at about 30 m.y. In the southern part of the basin the renewed spreading may have rifted the embryonic Lau Ridge from the Three Kings Rise. The new spreading phase may have been a response to changes in the relative motions of the Pacific and India plates (see below). The possibility that spreading in the basin continued while overthrusting took place in New Caledonia cannot be entirely ruled out.

If it is assumed that the spreading in the basin was symmetrical about a spreading ridge, since it is reasonably certain that the western part of the basin is older than the eastern, a two-stage evolution is required with a jump in the ridge location.

The alternative view that spreading was asymmetrical progressing from west to east is supported by a progressive increase of basin depth westwards and the interpretation of the ridge on the western flank of the Lau Ridge as an extinct spreading center. After the formation of the Norfolk Basin by eastward migration of the spreading ridge, new spreading could have commenced within the Three Kings Rise rifting off the Lau Ridge. The thinning of the sediment in the southeastern part of profile from Site 285 to 286 in the basin then would be due to the decrease in the intensity of volcanism to the south and the progressive decrease in volcanic accumulation as the volcanic sediments are laid down on progressively younger crust. A hiatus in seafloor formation may have occurred during the overthrusting phase in New Caledonia.

On either a symmetrical or asymmetrical spreading hypothesis, it is likely that sea-floor generation in the basin would have ceased in the late Oligocene.

\section{Deposition of the Kupe and Minerva Abyssal Plain Sediments}

In Northland in northern New Zealand, a change in the style of sedimentation occurred at the end of the Oligocene, with the commencement of calcalkaline volcanism (Leitch, 1970). There was a consequential increase in the supply of clastic sediment. It is likely then from the land geology that the thicker sediment pile of the Kupe Abyssal Plain commenced to accumulate from the end of the Oligocene onwards and terminated in the Pliocene. Minor contributions were probably made from southern Lau Ridge volcanoes.

The initial deposits on the Oligocene crust have been sampled only at Site 205 below the Minerva Abyssal Plain where there are ashy oozes indicating some volcanism in the late Oligocene. There is no evidence for such deposits in the southern part of the basin, although they could well be present.

The great influx of sediment into the Minerva Abyssal Plain was in the middle Miocene. This is a time when there was apparently a hiatus in volcanism in Fiji and it also marks the transition there from Gill's Island arc tholeiite suite to the calcalkaline suite (Gill, 1970; Gill and Gorton, 1973). On the Lau-Tonga Ridge it appears to have been when the present ridge crest was constructed on an older basement. The trend of the Fiji Islands presumably differed from that of the Lau-Tonga Ridge, so that the plate boundary near Fiji was near a transform direction between the Pacific and Indian plates. In the late Miocene, it appears that the relationship was reversed since there is abundant evidence of volcanism in Fiji and little on the Lau Ridge. As volcanism on the Lau Ridge declined in the late Miocene, possibly associated with the inital stages of rifting of the ridge to form the Lau-Havre Basin the sediments of the Minerva Abyssal Plain became more biogenic passing into oozes. As subsidence presumably resulting from lithosphere cooling and contraction continued the oozes were overlain from the early Pliocene onwards by abyssal clays.

\section{Late Miocene and Younger Tectonic Activity}

The commencement of subduction in the New Hebrides Trench in the late Miocene initiated the Hunter Fracture Zone at the northern margin of the basin. The gentle deformation of the northern part of the abyssal plain probably accompanied the development of the fracture zone. This deformation occurred after the thick clastic sequence of the abyssal plain had been laid down. The New Hebrides Trench has consumed a large area of crust of the New Hebrides-South Fiji Basin since the late Miocene as the Fiji Plateau has developed (Chase, 1971).

The end of the Miocene also marked other changes. The splitting of the Lau-Tonga Ridge commenced then and volcanism was initiated on the inner side of the Tonga Ridge. The main region of volcanism in New Zealand moved to the Coromandel Peninsula and then down into the Taupo region. Subsidence of the Northland Marginal Plateau took place in the Pliocene after volcanism on the Coromandel Peninsula had waned. The present fault scarp on the "Vening Meinesz 
Fracture Zone" was formed probably along an old dislocation. Late Tertiary volcanism in the southern part of the South Fiji Basin is indicated by seamounts formed late in the sedimentation history of the Kupe Abyssal Plain.

\section{PLATE MOTIONS}

Data on sea-floor spreading between Australia and Antarctica and on the Pacific south of New Zealand can be used to calculate the locations of poles of rotation of the Pacific plate relative to the India plate in order to try to determine the nature of the interaction between the Pacific plate and the arc system. These calculations (Table 5) have been based on Weissel and Hayes (1972) and Molnar et al. (1975). The stage poles calculated can be used as a rough approximation to instantaneous poles. The poles have then been rotated to show their location with the arc system fixed in its present position (Table 6, Figure 10). From 55 m.y., subsequent to the commencement of rifting of Australia from Antarctica, the pole of rotation has been about $11500 \mathrm{~km}$ east of the present plate boundary and has moved roughly parallel to it, southwards with time. The rotation of the Pacific plate relative to the Indian plate is counterclockwise. Since these poles are located relatively close to the plate boundaries, errors in the stage pole determinations for India/Antarctica and Pacific/Antarctica could significantly affect their location. Also, minor perturbations in either spreading rate could have had dramatic geological consequences in the region. Weissel and Hayes (1972), for example, suggest slowing of the spreading rate on the southeast Indian Ridge between anomalies 5 and $5 A$ (10-12 m.y.B.P.). The pole for 45 to $38 \mathrm{~m} . y$. would have been located east of the junction between the Tonga and Kermadec trenches. This accords reasonably well with the suggestion made above on geological grounds. The Eocene pole location accords with the Eocene subduction and consequential volcanism in Fiji and New Britain on the northern side of the arc and its absence on the eastern side of the arc system. The eastern side of the arc would have been a transform direction or a zone of extension. With time, the pole of relative rotation moved south to its present position south of New Zealand and the rate of subduction increased. The geometry is such that the volcanism on the northern side of the arc should have declined and that on the eastern side increased. This simple situation has become more complicated as a result of the Neogene reorientation and relocation of plate boundaries from time to time in the northern part of the arc system and a substantial amount of subduction has occurred, e.g., associated with the New Hebrides and Solomon islands.

The location of the stage poles relative to the arc system is not without problems as Molnar et al. (1975) point out. The passing of the plate boundary through New Zealand from 38 m.y. to the present can account for the bending of the New Zealand Geosyncline, but in attempting to arrive at a reconstruction for $45 \mathrm{~m}$.y., considerable overlap between the Lord Howe Rise and the Campbell Plateau (south of New Zealand) takes place. Molnar et al. tentatively solve this problem by suggesting opening between East and West Antarctica, but point out that other solutions are possible. Complexity of plate motions in the region is further suggested by the overlap between the Lord Howe Rise and Australia obtained by Hayes and Ringis (1973) in reconstructing the pre-Tasman Sea relationship. The same authors also note the possibility of minor subduction of Tasman Sea crust under eastern Australia. Complexities such as these render a geometric analysis of the region very tentative, especially for the Paleogene where it is evident from the geology of the islands that relocations of plate boundaries took place.

If the motions calculated are meaningful, the Eocene part of the South Fiji Basin may have formed as a response to arc migration in the north New Hebrides Basin and northwest South Fiji Basin and possibly extension in the southern part (?Norfolk Basin). The younger eastern part of the basin was developed when

TABLE 6

Pacific/India Poles of Rotation (India Plate Held Stationary)

\begin{tabular}{rcc}
\hline $\begin{array}{c}\text { Age } \\
\text { (m.y.) }\end{array}$ & Location & $\begin{array}{c}\text { Anticlockwise } \\
\text { Rotation of } \\
\text { Pacific Plate }\end{array}$ \\
\hline $0-10$ & $59.4^{\circ} \mathrm{S}, 175.7^{\circ} \mathrm{W}$ & $11.8^{\circ}$ \\
$10-21$ & $53.2^{\circ} \mathrm{S}, 174.6^{\circ} \mathrm{W}$ & $9.9^{\circ}$ \\
$21-29$ & $51.6^{\circ} \mathrm{S}, 175.5^{\circ} \mathrm{W}$ & $7.5^{\circ}$ \\
$29-38$ & $43.9^{\circ} \mathrm{S}, 156.2^{\circ} \mathrm{W}$ & $7.0^{\circ}$ \\
$38-45$ & $27.2^{\circ} \mathrm{S}, 153.6^{\circ} \mathrm{W}$ & $6.6^{\circ}$ \\
$45-55$ & $9.5^{\circ} \mathrm{S}, 159.7^{\circ} \mathrm{W}$ & $7.2^{\circ}$ \\
\hline
\end{tabular}

TABLE 5

Stage Poles Relative to Fixed Antarctica

\begin{tabular}{c|ccc|ccc|ccc}
\hline & \multicolumn{2}{|c|}{ India/Antarctica } & \multicolumn{3}{c|}{ Pacific/Antarctica } & \multicolumn{3}{c}{ Pacific/India } \\
Stage (m.y.) & Lat & Long & Rotation & Lat & Long & Rotation & Lat & Long & Rotation \\
\hline $0-10$ & $10.0^{\circ} \mathrm{S}$ & $144.75^{\circ} \mathrm{W}$ & $6.75^{\circ}$ & $68.7^{\circ} \mathrm{S}$ & $100.3^{\circ} \mathrm{E}$ & $9.4^{\circ}$ & $59.4^{\circ} \mathrm{S}$ & $175.7^{\circ} \mathrm{W}$ & $11.8^{\circ}$ \\
$10-21$ & $20.8^{\circ} \mathrm{S}$ & $152.2^{\circ} \mathrm{W}$ & $5.52^{\circ}$ & $76.7^{\circ} \mathrm{S}$ & $123.2^{\circ} \mathrm{E}$ & $6.4^{\circ}$ & $56.1^{\circ} \mathrm{S}$ & $167.7^{\circ} \mathrm{W}$ & $9.9^{\circ}$ \\
$21-29$ & $9.3^{\circ} \mathrm{S}$ & $148.0^{\circ} \mathrm{W}$ & $3.55^{\circ}$ & $77.3^{\circ} \mathrm{S}$ & $147.2^{\circ} \mathrm{E}$ & $5.8^{\circ} \mathrm{a}$ & $56.0^{\circ} \mathrm{S}$ & $163.9^{\circ} \mathrm{W}$ & $7.5^{\circ}$ \\
$29-38$ & $17.2^{\circ} \mathrm{N}$ & $128.5^{\circ} \mathrm{W}$ & $4.85^{\circ}$ & $77.3^{\circ} \mathrm{S}^{\mathrm{a}}$ & $147.2^{\circ} \mathrm{E}^{\mathrm{a}}$ & $6.5^{\circ} \mathrm{a}$ & $44.6^{\circ} \mathrm{S}$ & $145.1^{\circ} \mathrm{W}$ & $7.0^{\circ}$ \\
$38-45$ & $20.6^{\circ} \mathrm{N}$ & $137.3^{\circ} \mathrm{W}^{\mathrm{a}}$ & $5.10^{\circ} \mathrm{a}$ & $75.9^{\circ} \mathrm{S}$ & $178.2^{\circ} \mathrm{W}$ & $5.2^{\circ}$ & $29.3^{\circ} \mathrm{S}$ & $145.5^{\circ} \mathrm{W}$ & $6.6^{\circ}$ \\
$45-55$ & $20.6^{\circ} \mathrm{N}^{\mathrm{a}}$ & $137.3^{\circ} \mathrm{W}^{\mathrm{a}}$ & $7.28^{\circ} \mathrm{a}$ & $63.5^{\circ} \mathrm{S}^{\mathrm{a}}$ & $125.1^{\circ} \mathrm{E}^{\mathrm{a}}$ & $5.0^{\circ} \mathrm{a}$ & $15.5^{\circ} \mathrm{S}$ & $156.0^{\circ} \mathrm{W}$ & $7.2^{\circ}$ \\
$55-63$ & - & - & - & $63.5^{\circ} \mathrm{S}^{\mathrm{a}}$ & $125.1^{\circ} \mathrm{E}^{\mathrm{a}}$ & $4.0^{\circ} \mathrm{a}$ & $63.5^{\circ} \mathrm{S}$ & $125.1^{\circ} \mathrm{W}$ & $4.0^{\circ}$ \\
\hline
\end{tabular}

${ }^{a}$ Values interpolated by subdividing stage 38-45 m.y. of Weissel and Hayes (1972) and Stages 21-38, 45-63 of Molner et al. (1975). 
the Pacific-India pole of relative rotation was located southeast of the basin, and subduction along the eastern edge of the arc as evidenced by both the volcanism and the geometry had only proceeded to a minor extent. Basin development ceased when the pole moved further south and the rate of subduction increased, but commenced again approximately $5 \mathrm{~m} . \mathrm{y}$. ago with the onset of the formation of the Lau-Havre Basin.

\section{ACKNOWLEDGMENTS}

We would like to thank T.E. Chase of the Scripps Institution of Oceanography for making available the NOVA Expedition seismic profiles, Dr. J.E. Andrews of the University of Hawaii for supplying the Kana Keoki Leg 21 site survey seismic profiles, and Mr. T. Eade of the New Zealand Oceanographic Institute for the "Planksed" bathymetry. We have also benefited from discussions of interpretation of the seismic profiles with Dr. D.A. Falvey.

We also acknowledge the assistance of Diana Packham who drafted the text figures and Len Hay of the Department of Geology and Geophysics of the University of Sydney who drafted the map of the South Fiji Basin.

\section{REFERENCES}

Avias, J., 1967. Overthrust structure of the main ultrabasic New Caledonian massifs: Tectonophysics, v. 4, p. 531-542.

Berggren, W.A., 1972. A Cenozoic time-scale-some implications for regional geology and paleobiogeography: Lethaia, v. 5, p. 206.

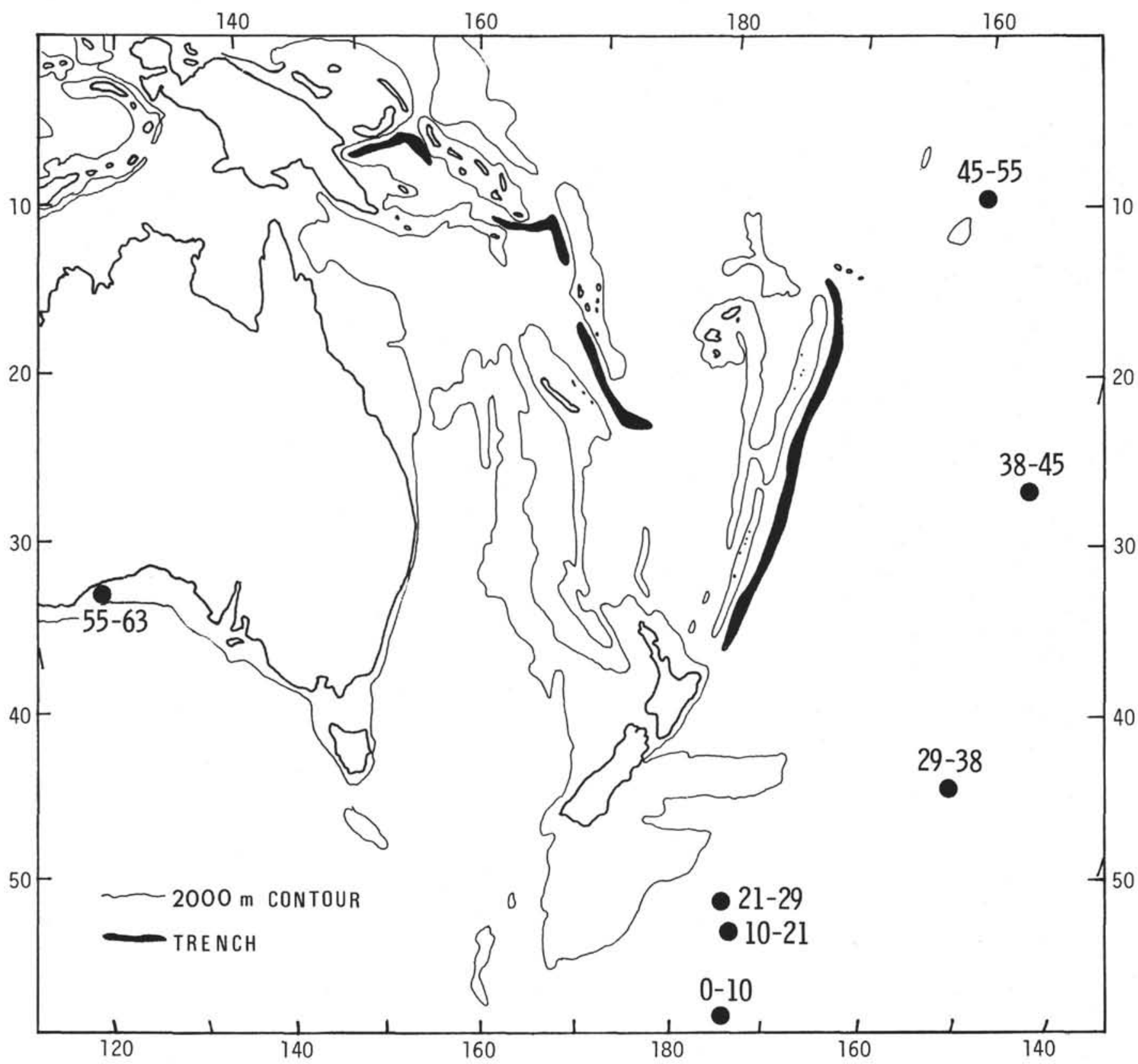

Figure 10. Stage poles for rotation of India/Pacific plates. Ages are given in millions of years. The rotation of the Pacific plate relative to the India plate is counterclockwise. The amounts of relative rotation are given in Table 5. 
Brothers, R.N. and Blake, M.C., 1973. Tertiary plate tectonics and high pressure metamorphism in New Caledonia: Tectonophysics, v. 17, p. 337-35.

Bukry, D., 1973. Coccolith and silocoflagellate stratigraphy, Tasman Sea and southwestern Pacific Ocean. In Burns, R.E., Andrews, J.E., et al., Initial Reports of the Deep Sea Drilling Project, Volume 21: Washington (U.S. Government Printing Office), p. 885.

Burns, R.E., Andrews, J.E., et al., 1973. Initial Reports of the Deep Sea Drilling Project, Volume 21: Washington (U.S. Government Printing Office), p. 932.

Chase, C.G., 1971. Tectonic history of the Fiji Plateau: Geol. Soc. Am. Bull., v. 82, p. 3087.

Churkin, M., Jr., and Packham, G.H., 1973. Volcanic rocks and volcanic constituents in sediments, Leg 21, Deep Sea Drilling Project. In Burns, R.E., Andrews, J.E., et al., Initial Reports of the Deep Sea Drilling Project, Volume 21: Washington (U.S. Government Printing Office), p. 481.

Cullen, D.J., in press. Kandavu bathymetry: New Zealand Oceanogr. Inst. Chart. Oceanic series 1:1,000,000.

Ewart, A. and Bryan, W.B., 1972. Petrography and geochemistry of the igneous rocks from Eua, Tongan Islands: Geol. Soc. Am. Bull. 83, p. 3281.

Fleming, C.A., 1969. The Mesozoic of New Zealand, history of the circum-Pacific mobile belt: J. Geol. Soc. London, v. 125 , p. $125-170$.

Gill, J., 1970. Geochemistry of Viti Levu, Fiji, and its evolution as an island arc: Contrib. Mineral. Petrol., v. 27, p. 179.

Gill, J. and Gorton, M., 1973. A proposed geological and geochemical history of Eastern Melanesia. In Coleman, P.J. (Ed.), The Western Pacific, Island Arcs, Marginal Seas, geochemistry: Western Australia (University of Western Australia Press).

Gill, J.B. and McDougall, I., 1973. Biostratigraphic and geological significance of Miocene-Pliocene volcanism in Fiji: Nature, v. 241, p. 176.

Guillon, J.H. and Routhier, P., 1971. Les stades d'evolution et de mise en place des massifs ultramafiques de nouvelleCaledonie: Bur. Rech. Geol. Min. Bull., v. 4.

Hayes, D.E. and Ringis, J., 1973. Sea-floor spreading in a marginal basin: The Tasman Sea: Nature, v. 243, p. 86-88.

Hoffmeister, J.E., 1932. Geology of Eua, Tonga: Bernice P. Bishop Mus. Bull., v. 96, p. 93, Honolulu (Museum Press).

Karig, D.E., 1970a. Kermadec Arc-New Zealand tectonic confluence: New Zealand J. Geol. Geophys., v. 13, p. 21.

D.E., 1970b. Ridges and basins of the TongaKermadec Island Arc system: J. Geophys. Res., v. 75, p. 239.

Kear, D. and Hay, R.F., 1961. Sheet 1, North Cape (1st ed.). Geological Map of New Zealand 1:250,000: Wellington, New Zealand (Department of Scientific and Industrial Research).

Ladd, H.S. and Hoffmeister, J.E., 1945. Geology of Lau, Fiji: Bernice P. Bishop Mus. Bull., v. 181. Honolulu (Museum Press).

Leitch, E.C., 1970. Contributions to the geology of northern- most New Zealand: the stratigraphy of the North Cape district: Roy. Soc. New Zealand Earth Sci. Trans., v. 8, p. $45-68$.

Lillie, A.R. and Brothers, R.N., 1970. The geology of New Caledonia: New Zealand J. Geol. Geophys., v. 13, p. 145183.

Mammerickx, J., Chase, T.E., Smith, S.M., and Taylor, I.L., 1971. Bathymetry of the South Pacific, Chart 12: La Jolla, Calif. (Scripps Institution of Oceanography).

Mitchell, A.H.G. and Warden, A.J., 1971. Geological evolution of the New Hebrides island arc: J. Geol. Soc., v. 127, p. 501-529.

Molnar, P., Atwater, T., Mammerickx, J., and Smith, S.M., 1975. Magnetic anomalies, bathymetry and tectonic evolution of the South Pacific since the Late Cretaceous: Geophys. J. Roy. Astron. Soc., v. 40, p. 383.

Rodda, P., 1967. Outline of the geology of Viti Levu: New Zealand J. Geol. Geophys., v. 10, p. 1260.

Rodda, P., Snelling, N.J., and Rex, D.C., 1967. Radiometric age data on rocks from Viti Levu, Fiji: New Zealand J. Geol. Geophys., v. 10, p. 1248.

Schofield, J.C., 1967. Sheet 3, Auckland (1st ed.). Geological Map of New Zealand 1:250,000. Wellington, New Zealand (Department of Scientific and Industrial Research).

Sclater, J.G., 1972. Heat flow and elevation of the marginal basins of the western Pacific: J. Geophys. Res., v. 77, p. 5705-5719.

Sclater, J.G., Ritter, U.G., and Dixon, F.S., 1972. Heat flow in the southwestern Pacific: J. Geophys. Res., v. 77, p. 5697-5704.

Shor, G.G., Kirk, H.K., and Menard, H.W., 1971. Crustal structure of the Melanesian area: J. Geophys. Res., v. 76, p. 2562-2586.

Speight, R., 1910. Petrological notes on rocks from the Kermadec Islands with some evidence for the existence of a subtropical Pacific continent: New Zealand Inst. Trans., v. 42 , p. $241-254$.

Stearns, H.T., 1971. Geologic setting of an Eocene fossil deposit on Eua Island, Tonga. Geol. Soc. Am. Bull., v. 82, p. 2541 .

Stipp, J.J. and Thompson, B.N., 1971. K/Ar ages from the volcanics of Northland, New Zealand: New Zealand J. Geol. Geophys., v. 14, p. 403.

Thompson, B.N., 1960. Sheet 2B Barrier (1st ed.). Geological Map of New Zealand 1:250,000: Wellington, New Zealand (Department of Scientific and Industrial Research).

van der Linden, W.J.M., 1967. Structural relationships in the Tasman Sea and southwest Pacific Ocean: New Zealand J. Geol. Geophys., v. 10, p. 1280.

1968. Three Kings bathymetry: New Zealand Oceanogr. Inst. Chart. Oceanic Series 1:1,000,000.

Wanoa, R.J. and Lewis, K.B., 1972. Gazetteer of the seafloor features in the New Zealand region: New Zealand Oceanogr. Inst. Records, v. 1, p. 67.

Weissel, J.K. and Hayes, D.E., 1972. Magnetic anomalies in the southeast Indian Ocean. In Haigs, D.E. (Ed.). Antarctic Oceanology II: The Australian-New Zealand sector, Antarctic Res. Ser., Volume 19: Washington (American Geophysical Union). 


\section{PLATE 1}

(In pocket at back of volume)

\section{PLATE 2}

Scanning electron micrographs of glass shards.

Shards and pumice of essentially acid and acid-intermediate composition.

Figure 1 Sample 205-7-1, 81-32 cm. 60 meters below sea floor, Late Miocene. Mixture of the various morphological types of acid and acid/intermediate shards. $\times 75$.

Figures 2, 3 Pumice, with very fine vesicules and very high vesicularity.

2. Sample $205-2-2,86 \mathrm{~cm}$. 10 meters below sea floor, Pliocene-Pleistocene? $\times 75$.

3. Sample 285 A-2-1, $24-25 \mathrm{~cm}$. 180 meters below sea floor, upper middle Miocene. $\times 500$.

Figures 4-6 Shards showing "pipe" vesicules, with high vesicule densities and thin vesicule walls.

4. Sample 205-7-1, 81-82 cm. 60 meters below sea floor, late Miocene. $\times 225$.

5. Sample $285 \mathrm{~A}-2-1,24-25 \mathrm{~cm}$. 180 meters below sea floor, upper middle Miocene. $\times 225$.

6. Sample 205-11-1, 140-145 cm. 100 meters below sea floor, upper middle Miocene. $\times 750$.

Figures 7-9 Showing thin platy and angular shards resulting from the break-up of glass with a high density of large vesicules.

7. Sample $205-5-6,120-121 \mathrm{~cm}$. 50 meterr below sea floor, late Miocene. $\times 225$.

8. Sample 205-7-1, 81-82 cm. 60 meters below sea floor, late Miocene. Angular shard formed from the broken wall between two (or more) elongated vesicules. $\times 225$.

9. Sample $285-5-1,81-83 \mathrm{~cm}$. 70 meters below sea floor, late Miocene. Y-shaped shard formed from the broken wall between three (or more) ovoid vesicules. $\times 500$. 
PLATE 2
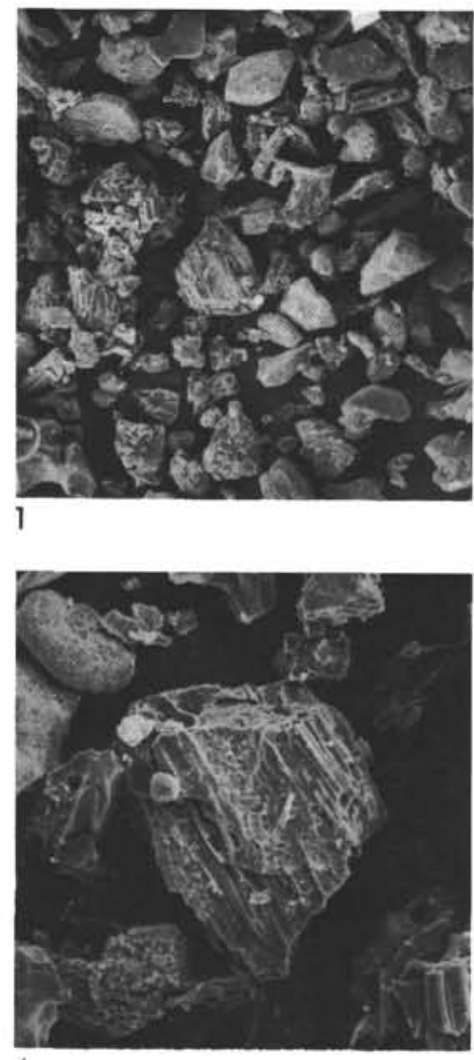

4

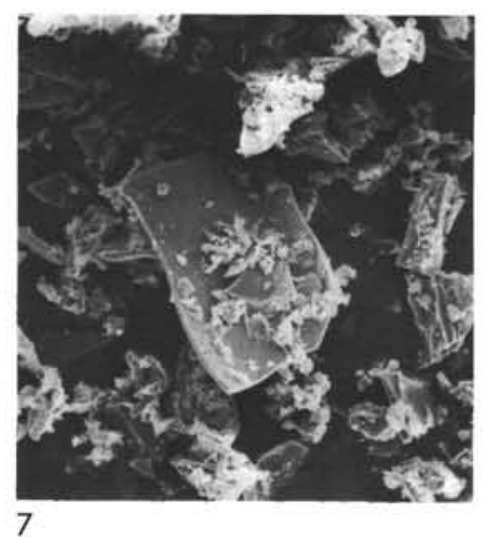

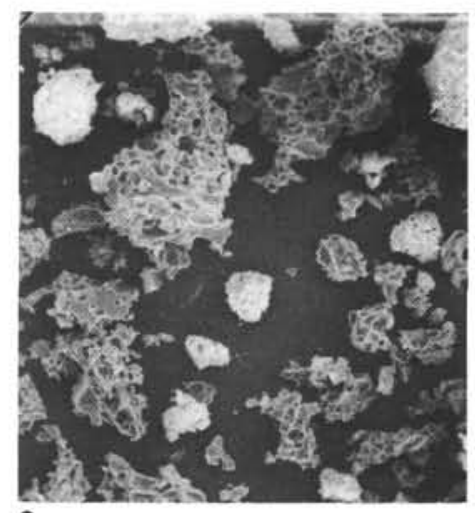

2
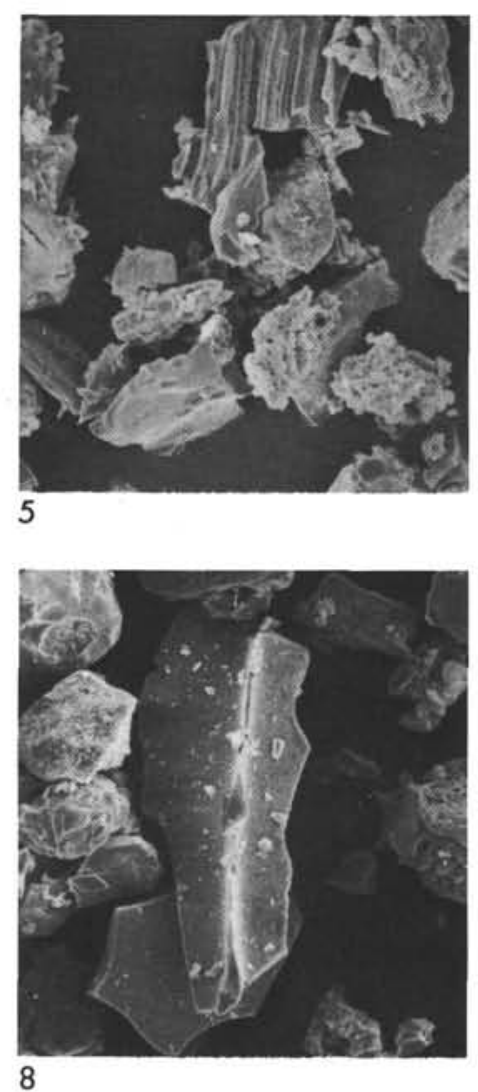
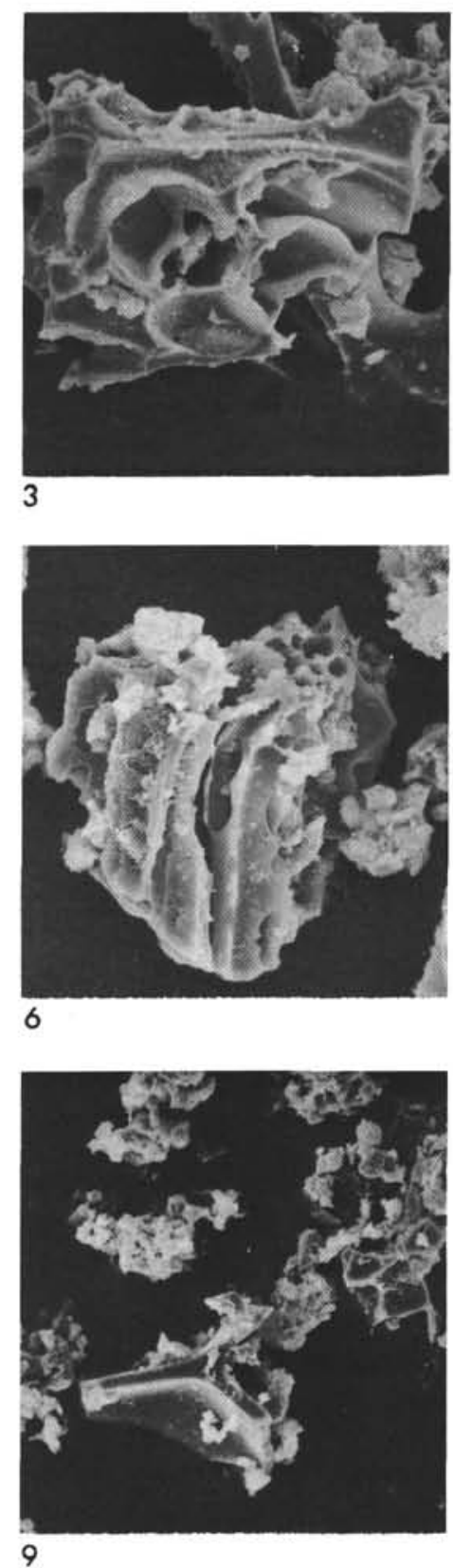


\section{PLATE 3}

Scanning electron micrographs of glass shards. Shards of essentially basic and basic-intermediate composition.

Figure 1

Sample 205-8-3, $85-86 \mathrm{~cm}$. 70 meters below sea floor, late Miocene. Single equant shard showing low vesicularity, part of a broken droplet. The identations with the smooth edges are vesicules that have broken through the droplet skin while the glass was still fluid. $\times 75$.

Figure 2 Sample 285A-1-1, 105-108 cm. 13 meters below sea floor, late Miocene. Equant shards showing low vesicularity and thick vesicule walls. The smooth fracture surfaces on the largest shard may be due to the lava shattering on contact with seawater. $\times 225$.

Figure 3, 4 Sample 205-6-3, $48-49 \mathrm{~cm}$. 50 meters below sea floor, late Miocene. Angular shards with few vesicules and thick vesicule walls. The large vesicule cavities contain a number of smaller cavities with smooth edges. These smaller vesicules have broken through into the large vesicules while the glass was still molten. The fracture surfaces are generally rough with some cracking (as in the large shard in Figure 3) suggesting mechanical break-up of the shards after cooling. $\times 75$.

Figures 5, 6 Site 205-7-1, 81-83 cm. 60 meters below sea floor, late Miocene. Showing mixture of shards with few vesicules and thick vesicule walls with shards of a more acid composition and different morphologies (see Plate 2).
5. $\times 225$

6. $\times 75$. 
PLATE 3

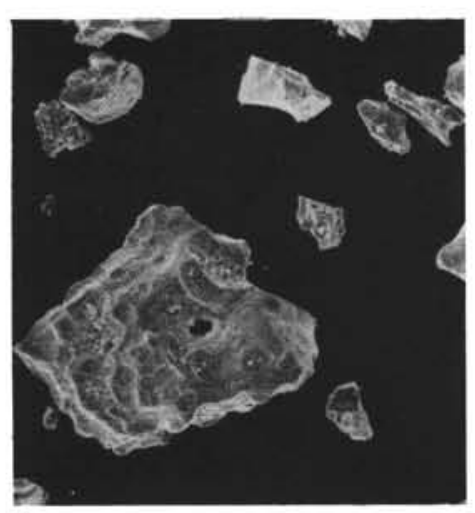

1

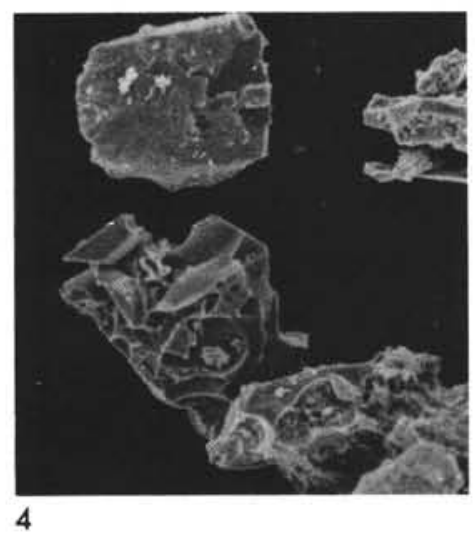

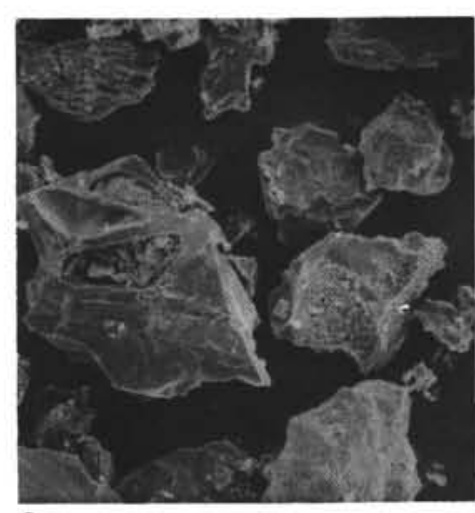

2

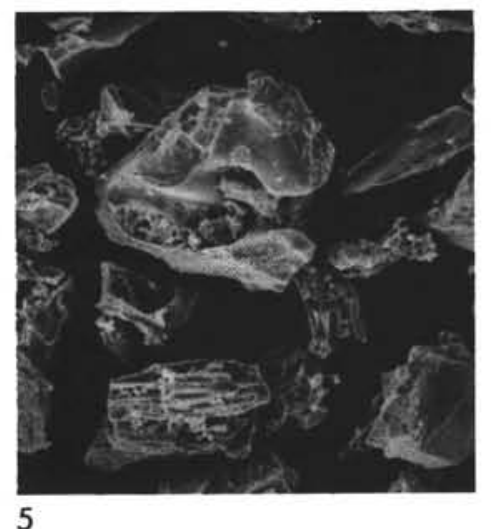

5

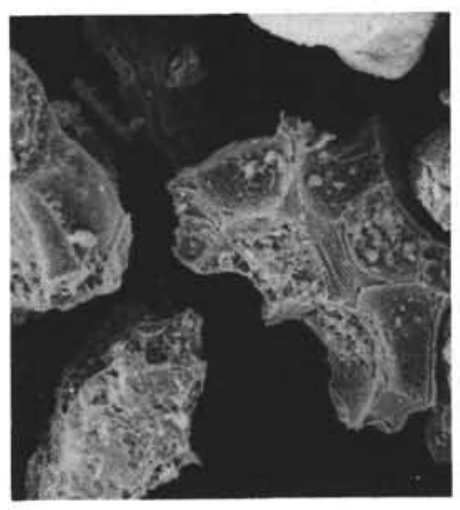

3

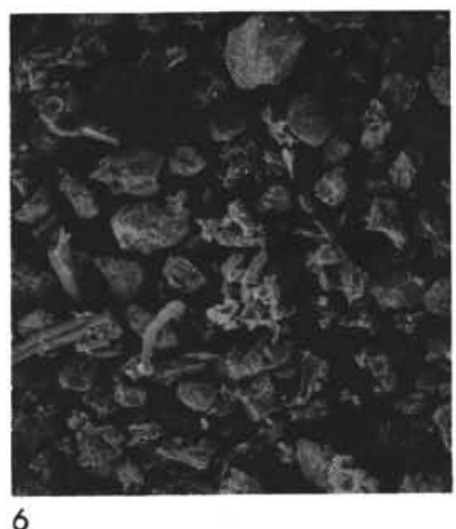


PLATE 4

Seismic Profiles across the Lau Ridge

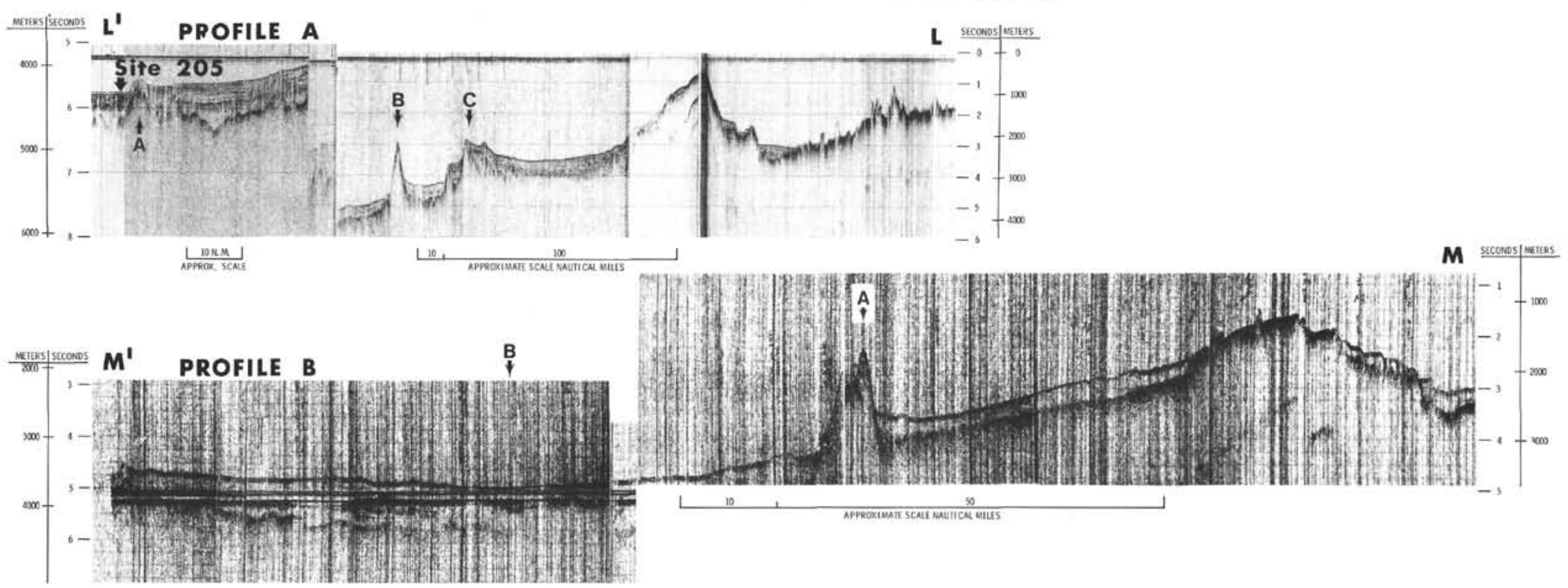

Profile A (L to L')-DSDP Leg 21 (1971). Lau Ridge with terraced basins on the western flank, basement highs at A and C, the intrusion at B and normal faults. Note change in seismic character of sediment across ridge A just east of Site 205.

Profile B (M to M')-Kana Keoki Leg III (1971). Lau Ridge with extensive faulting on eastern flank and two minor intrusions. The hill at A is isolated and possibly an intrusion. Note thick sediment cover and smooth slope into the broad isolated basin B. The record to the west is poor but there is some evidence of a hill, or series of hills, with a final scarp dropping into the South Fiji Basin proper. 


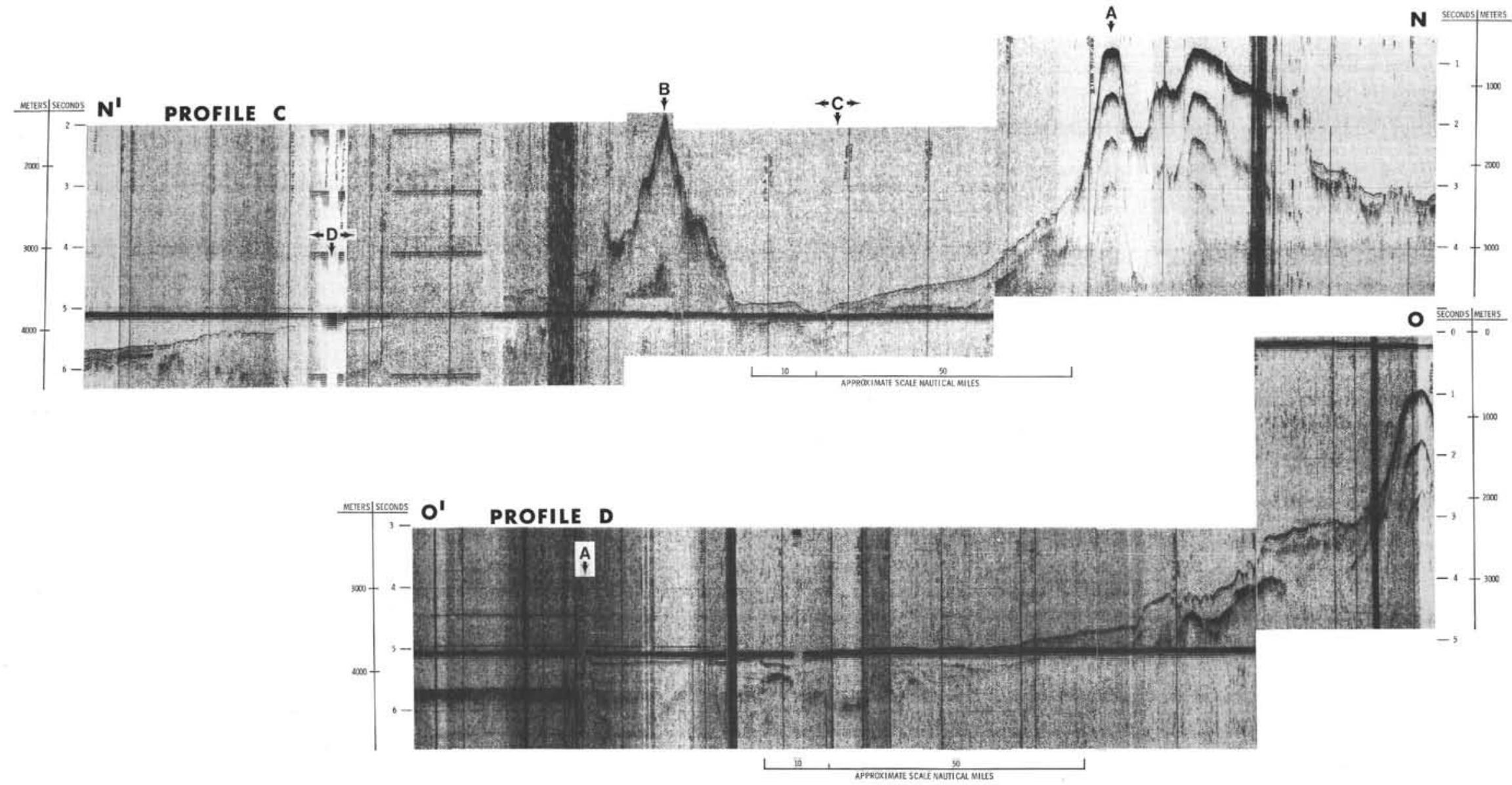

Profile C

Profile D

(N to N')-Nova Argo Leg VI (1967). Lau Ridge with faulting on the eastern flank and secondary ridge A on the western flank. Hill B is a ridge trending east-west for approximately $100 \mathrm{~km}$. Note thick sediment fill in basin C and on the slope D. Sediment is slumped in basin C and faulted on the west side on hill B.

(O to O')-Nova Argo Leg V (1967). The steep western upper flank of the Lau Ridge with abrupt change of slope to the thick faulted and slumped sediment. Disturbed sediment and an irregular basement extend under the broad plain that terminates at a scarp A at the edge of the South Fiji Basin proper. This scarp may be either a fault or a part-buried basement ridge. 
PLATE 5

Profiles of the Southern Margin of the South Fiji Basin

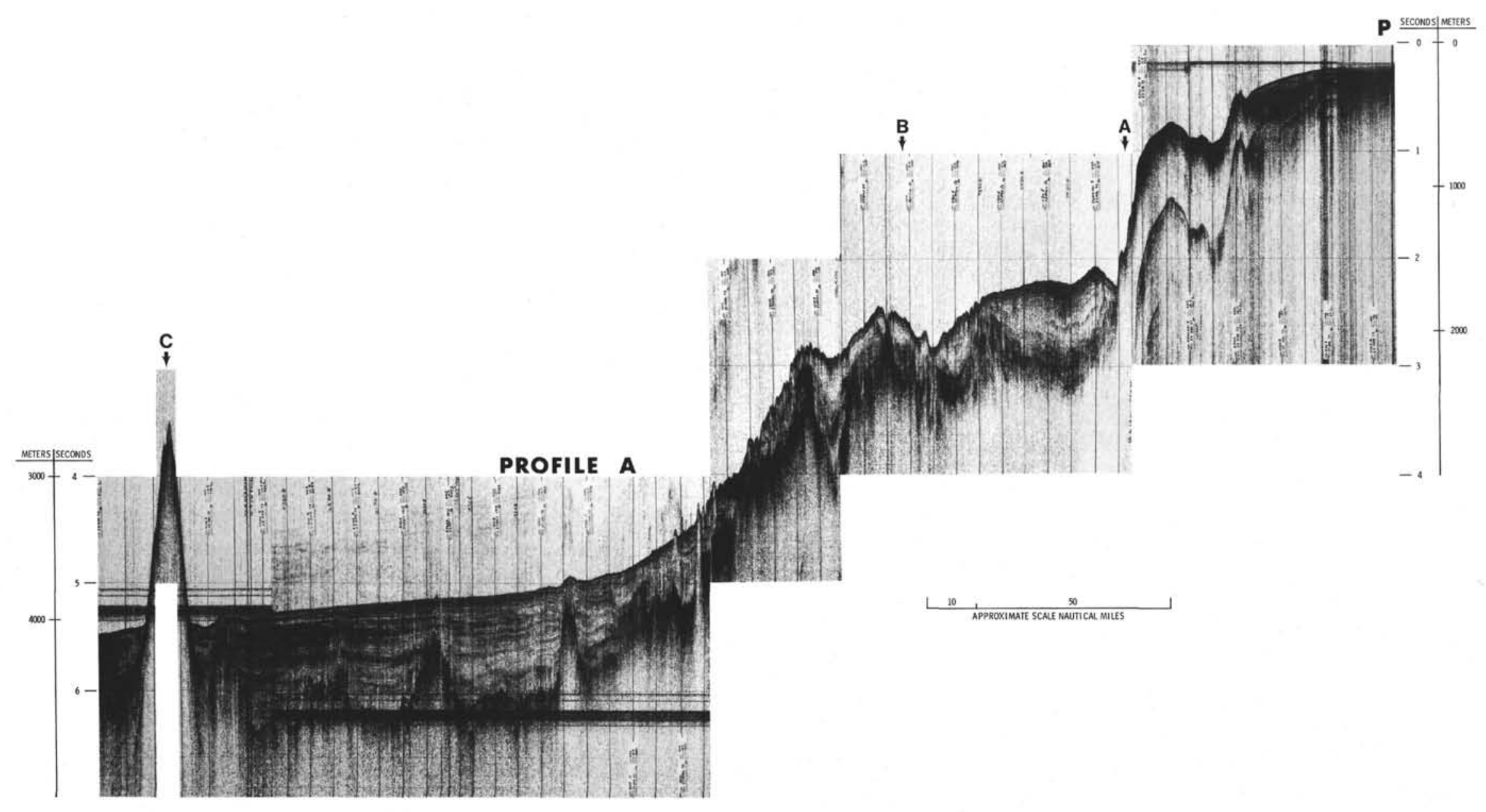




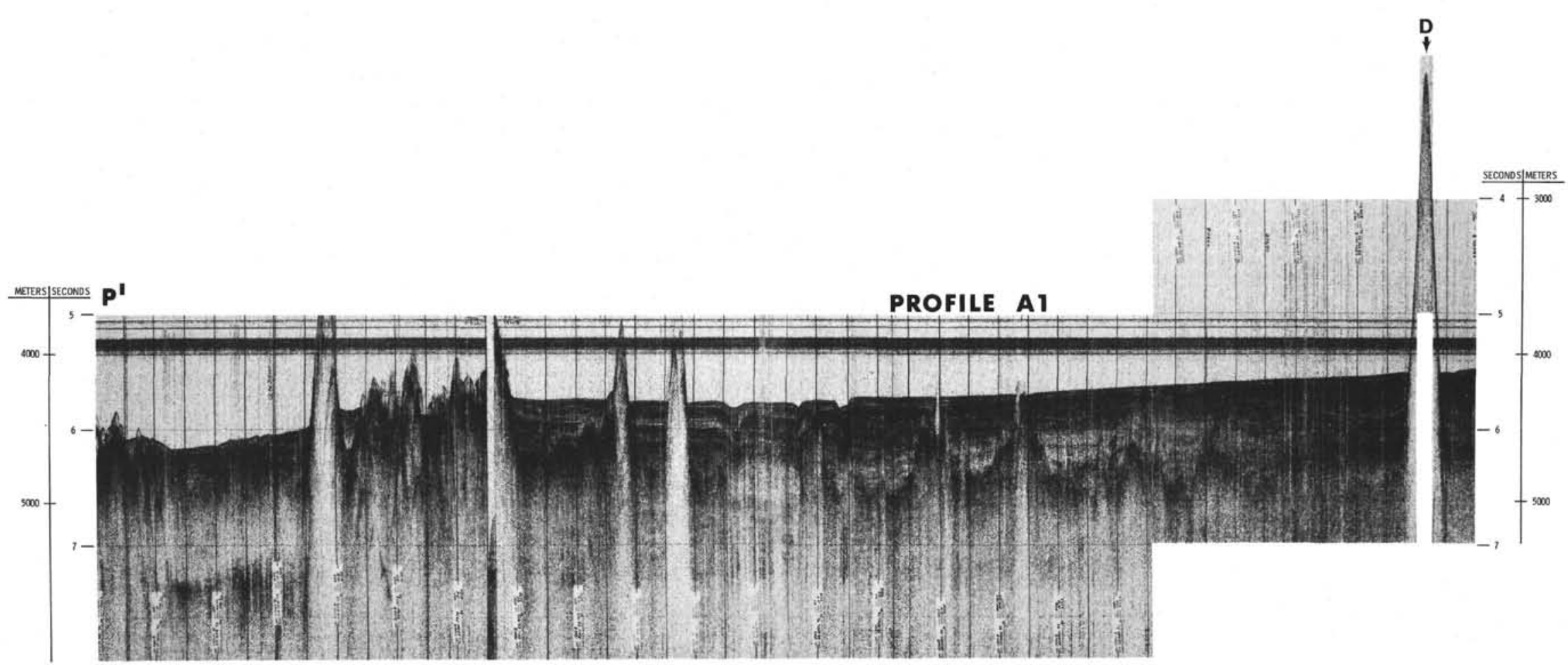

Profile A

(P to $\mathrm{P}^{\prime}$ )-DSDP Leg 30 (1973). Note the thin sediment cover prograding northwards from Cuvier Island across the continental shelf and upper slope, unconformably over older sediment, the main scarp of the Vening Meinesz Fracture Zone at A, and the disturbed sediment on the Northland Marginal Plateau with thin unconformable hemipelagic cover. To the north is the Kupe Abyssal Plain with a gentle northwards slope. Channels are evident in the lower part (Profile A1) as are seamounts at C and D. Abyssal plain sediments are ponded by the Central ridge at the distal end, with minor spilling onto deeper parts of Minerva Abyssal Plain. 
PLATE 6

Profiles across the Western and Northern Areas of the South Fiji Basin
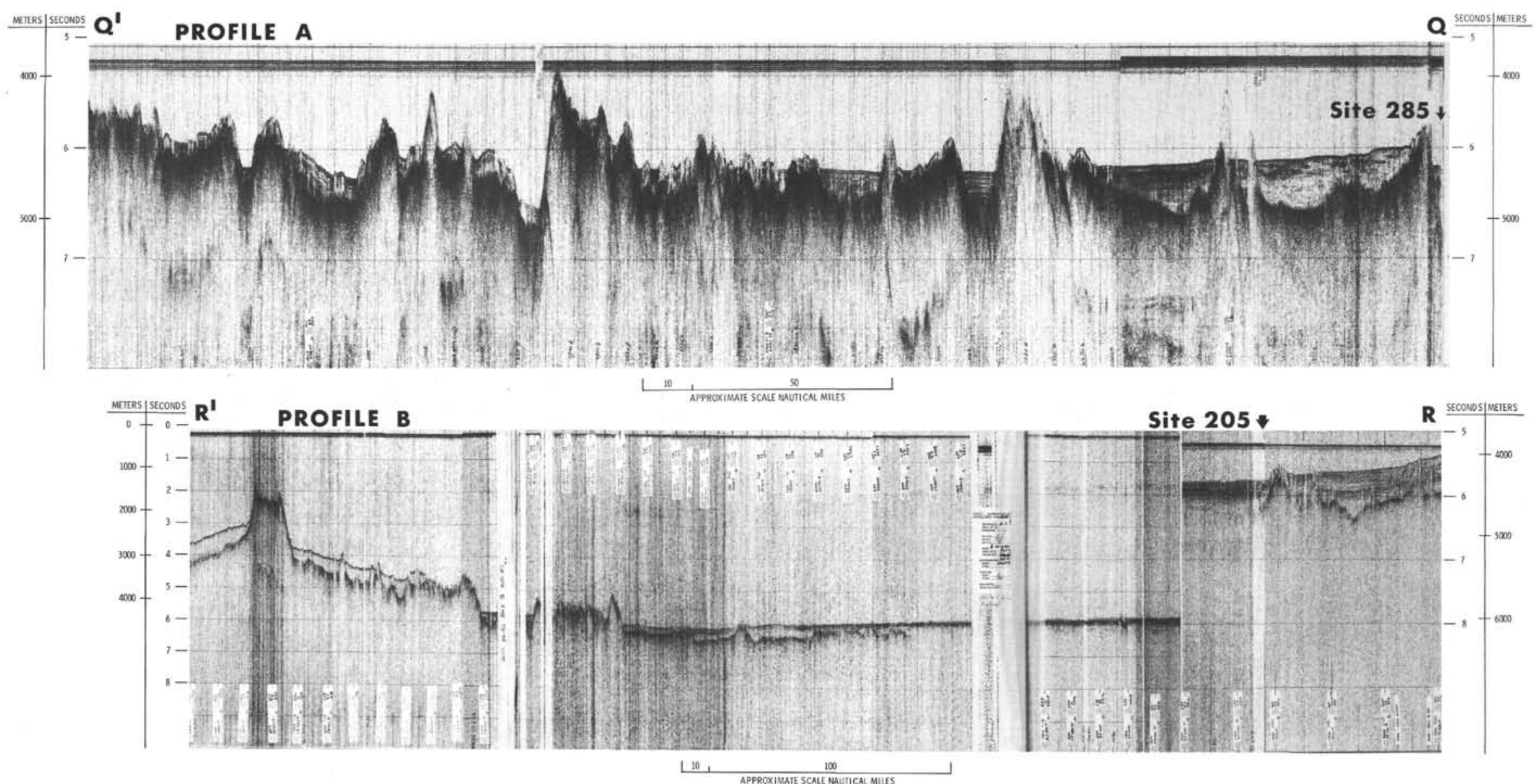

Profile A

(Q to $Q^{\prime}$ )-DSDP Leg 30 (1973). Flat-lying middle Miocene to Pleistocene sediments of the Minerva Abyssal Plain are absient to the northwest of A. Past this point is rough basement overlain by a southeasterly thinning clastic wedge that is unconformably overlain by the Minerva Abyssal Plain sediments to the south.

Profile B ( $\quad$ to $\mathrm{R}^{\prime}$ )-DSDP Leg 21 (1971). Note the east to west slope of the Minerva Abyssal Plain, the rough topography at the western margin of the basin and the thick sediment drape over the flanks of the Three Kings Rise. 


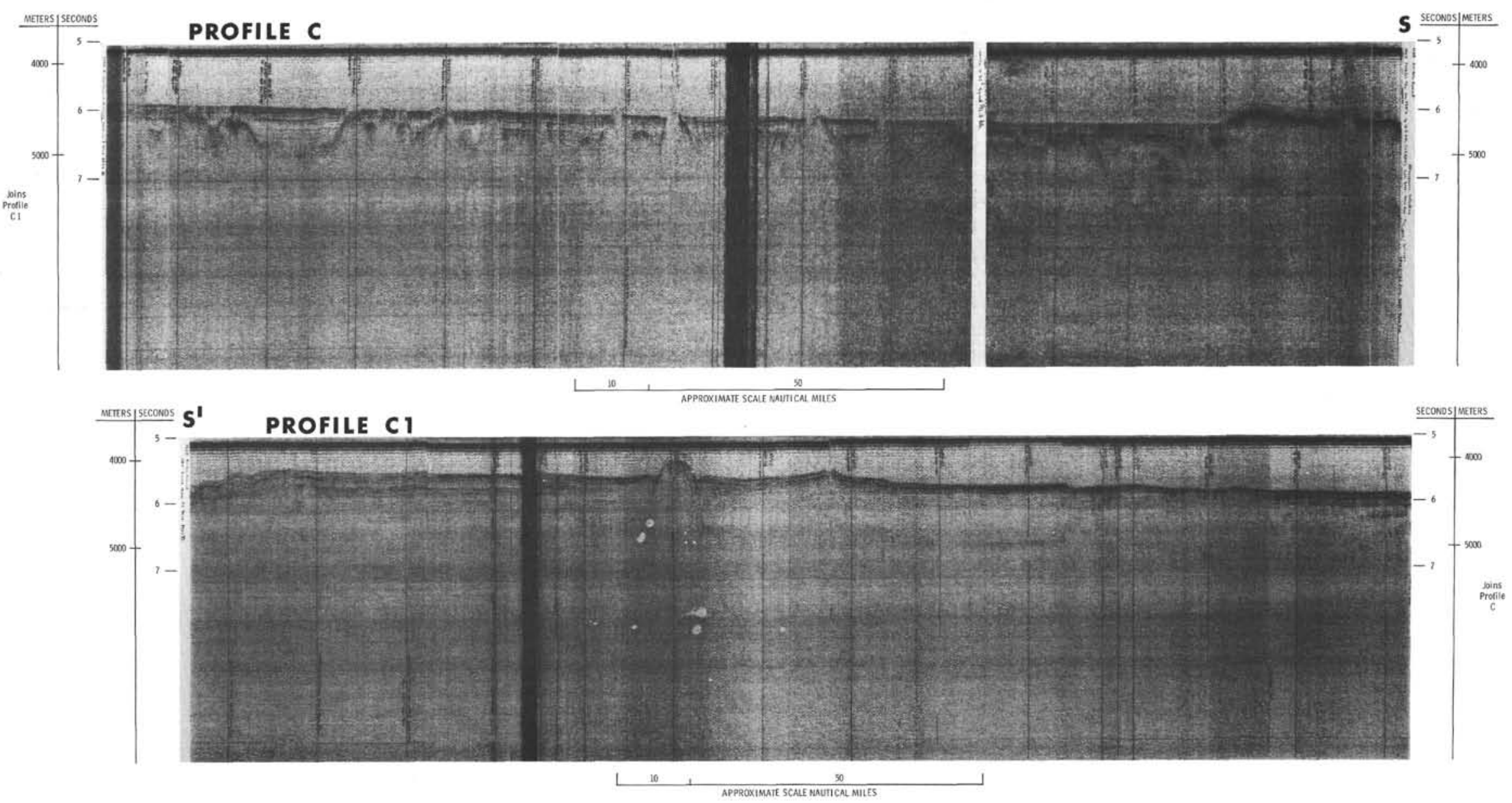

Profiles C, C1 (S to S') - Nova Argo Leg VI (1967). Note the overall slope of the Minerva Abyssal Plain from north to south. Sediments are essentially flat lying and seismic reflectors converge towards the south. Sediments are increasingly disturbed northwards toward the Hunter Fracture Zone area. 
PLATE 7

Profiles in the Central Area of the South Fiji Basin
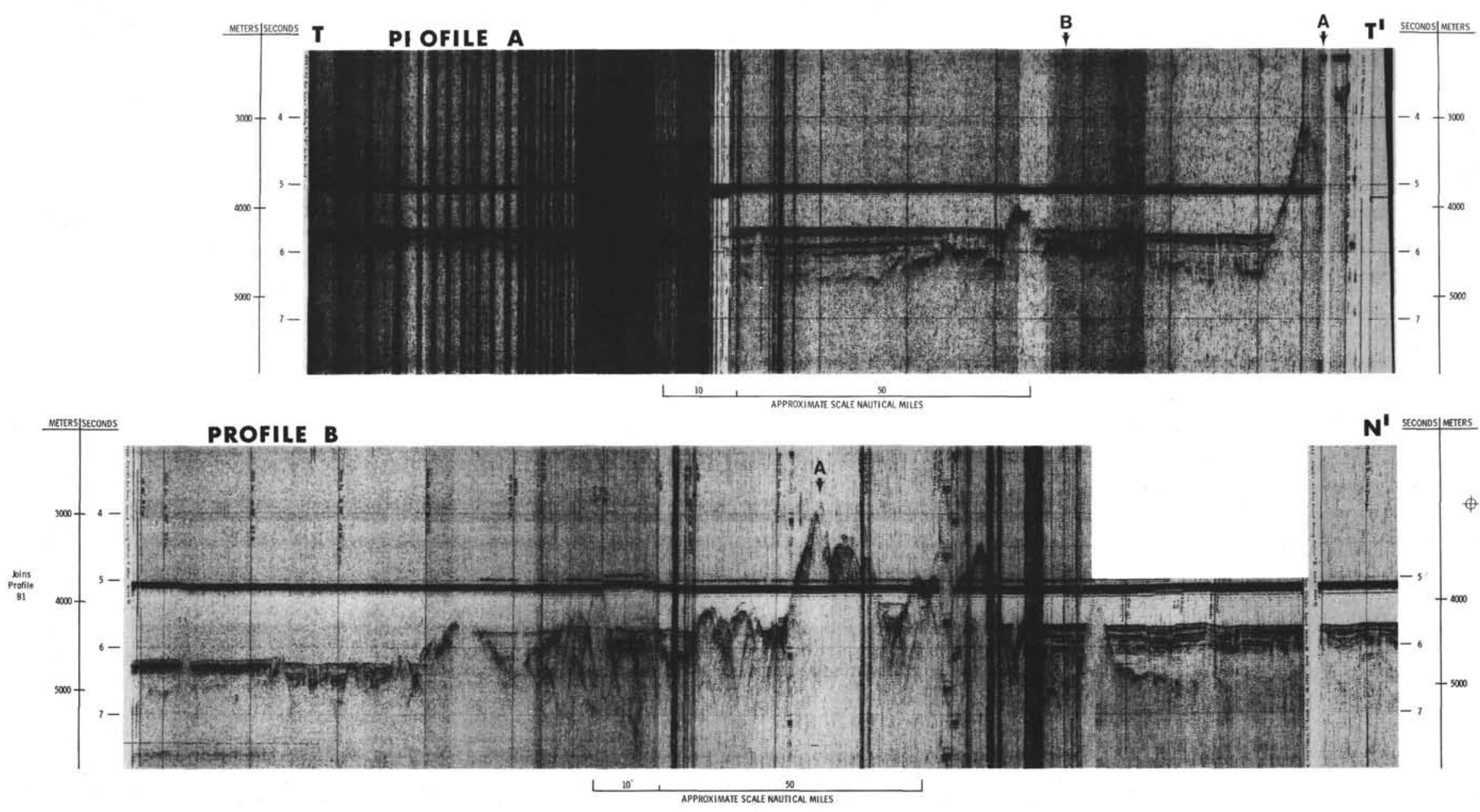

Profile A (T to T')-Nova Argo Leg V (1967). East-west profile across northern Kupe Abyssal Plain. Upper part of sediment shows bulge in basin center which is a cross-section of the clastic fan from New Zealand. A is a NE-SW trending ridge on the flank of the Three Kings Rise and basement highs appear at B. 

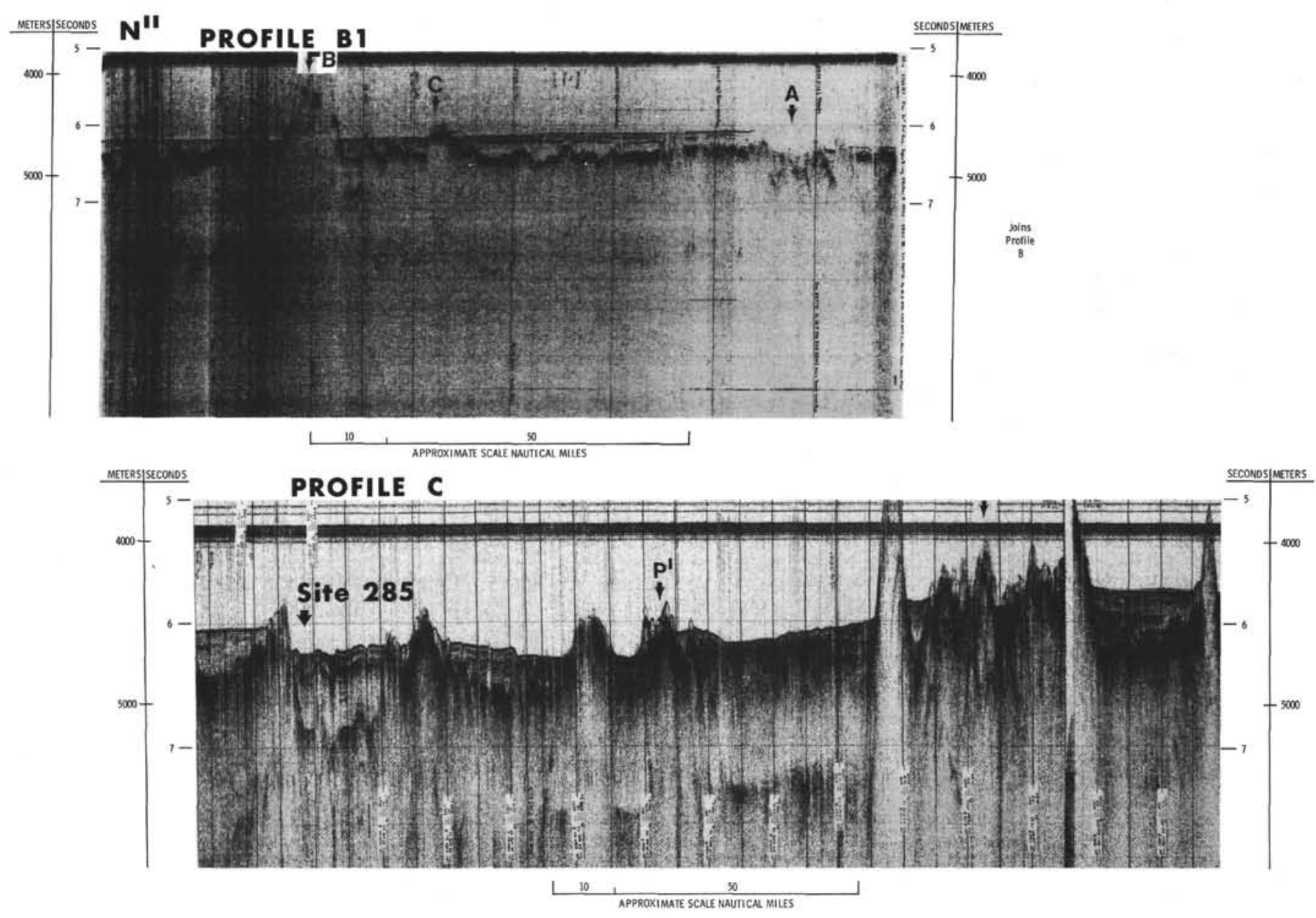

Profiles B, B1 ( $\mathrm{N}^{\prime}$ to $\left.\mathrm{N}^{\prime \prime}\right)$ Nova Argo Leg VI (1967).

B. Central ridge A separating Kupe Abyssal Plain from Minerva Abyssal Plain. Upper level is Kupe Abyssal Plain.

B1. Minerva Abyssal Plain sediments showing lateral changes in seismic character, particularly across scarp A. Note basement hills B and C and deep sediment-filled hole between them.

Profile C DSDP Leg 30 (1973). (Overlaps Profic ship between the sediments of the Kupe and Minerva Abyssal plains. The northern extremity of the Kupe Abyssal Plain is shown on the southern end of this profile. The series of highs at A are part of the same structure shown at point A on Profile B. Disturbed sediments occur immediately south of Site 285 . 